\title{
Patrimônio musical bibliográfico na Seção de Obras Raras da Biblioteca Fran Paxeco do Grêmio Literário e Recreativo Português em Belém do Pará: um estudo acerca de memórias e identidades em uma coleção especial
}

Bibliographic musical heritage in the Rare Works Section of the Fran Paxeco Library of the Portuguese Literary and Recreational Society in Belém do Pará: a study on memories and identities in a special collection

Fernando Lacerda Simões Duarte ${ }^{1}$ Escola de Música da UFPA lacerda.lacerda@yahoo.com.br 


\section{Resumo}

Embora menos mencionados no campo da musicologia histórica no Brasil do que os arquivos, os acervos das bibliotecas também contêm fontes de interesse para o estudo da música. Neste trabalho, busca-se compreender a constituição da Seção de Obras Raras da Biblioteca do Grêmio Literário e Recreativo Português do Pará, observando-se indícios que sugiram ou afastem a hipótese de que os itens da seção e, mais especificamente, aqueles de interesse musical - manual de procissões, livros de teoria e libretos encadernados, datados dos séculos XVII e XVIII - tenham tido usos locais ao tempo de sua produção. Para tanto, foi pesquisa de campo no Pará e em Lisboa, recorrendo-se ainda ao quadro teórico de Cataldo e Loureiro, Mouren e Candau. Os resultados apontam para a provável aquisição dos itens bibliográficos no século XIX, que, embora não pareçam ter relação com práticas musicais locais, sua seleção reflete a afirmação intencional de uma identidade luso-amazônida.

Palavras-chave: Marcas de proveniência; patrimônio musical bibliográfico; história religiosa da Amazônia; memórias, identidades e acervos; livrarias das casas religiosas de Lisboa.

\section{Abstract}

Although less discussed in the field of historical musicology in Brazil than archives, library collections also contain sources of interest to the study of music. This article seeks to understand the constitution of the rare works section of the library of Grêmio Literário e Recreativo Português [Portuguese Literary and Recreational Society] of Pará, observing signs that suggest or rule out the hypothesis that the items in the section and, more specifically, those of musical interest - a book for processions, theory books and bound librettos, dating from the 17th and 18th centuries - have taken local uses at the time of their production. For this purpose, a fieldwork was carried out in Pará and Lisbon, using the theoretical framework of Cataldo and Loureiro, Mouren and Candau. The results point to the probable acquisition of bibliographic items in the 19th century, which, although they do not seem to be related to local musical practices, their selection reflects the intentional affirmation of a Luso-Amazonian identity.

Keywords: Provenance marks; Bibliographic musical heritage; Religious history of the Amazon; Memories, identities and collections; Libraries of the convents of Lisbon.

Professor da Escola de Música da Universidade Federal do Pará (EMUFPA). Doutor em Música pela UNESP. Realizou estágios pós-doutorais junto ao PPG-Música/UFMG e PPG-Artes/UFPA, ambos com bolsax PNPD/CAPES. 


\section{Introdução}

A noção de acervos musicais históricos no Brasil tende a remeter imediatamente aos acervos de bandas de música, aos arquivos pessoais de músicos e aos grandes acervos que se encontram hoje em instituições de custódia permanente. Se as coleções das bibliotecas podem parecer, nesse contexto, secundárias, fato é que elas têm abrigado parte dos acervos de relevância para a Musicologia histórica no país. A coleção D. Thereza Christina, na Biblioteca Nacional, o acervo de Francisco Curt Lange, na Biblioteca da Universidade Federal de Minas Gerais, e o de Vicente Salles, na Biblioteca do Museu da Universidade Federal do Pará, exemplificam tais situações de recolhimento. Há de se notar, entretanto, o fato de que tais acervos são, em parte, coleções empreendidas por pesquisadores, em parte coleções familiares que foram recolhidas a tais instituições, e se perguntar a razão de as coleções das próprias bibliotecas não figurarem com destaque no rol dos acervos musicais. Uma resposta possível talvez esteja na distinção entre arquivos e bibliotecas e na expectativa de se estudarem os acontecimentos relativos às práticas musicais nos arquivos musicais mais do que elas provavelmente se revelariam por meio das coleções. Neste sentido,

A virtude dos arquivos é por-nos em contato com a pura historicidade [...]: por um lado, constituem o acontecimento na sua contingência radical, [...] mas também estabelecem uma existência física à histórica, porque neles apenas fica superada a contradição de um passado terminado e de um presente, em que ele sobrevive. Os arquivos são o ser encarnado da "acontecimentalidade". (LÉVI-STRAUSS, 1976, p.273).

Por outro lado, a expectativa da existência de arquivos musicais "puros" parece incompatível com a natureza das próprias agremiações voltadas às práticas musicais coros, bandas de música e orquestra -, que muitas vezes recebem acervos de outras instituições, tanto para a interpretação musical quanto simplesmente para a guarda, quando o repertório registrado nas fontes não mais encontra interesse no público. $O$ plano factual revela, nesse caso, a não aplicabilidade de determinados princípios arquivísticos (BELLOTTO, 2002, p.25), tais como a unicidade, a imparcialidade, a autenticidade, mas, sobretudo, a naturalidade e a organicidade (DUARTE, 2019). No tocante à distinção entre as características dos acervos recolhidos que integram arquivos e bibliotecas, tem-se que

[...] podemos definir a biblioteca como a instituição que reúne documentos múltiplos, por compra, doação ou permuta, produzidos por fontes diversas e resultantes de atividades, pesquisas ou criações artísticas, técnicas ou científicas com fins culturais e de ensino e instrução. Arquivo é a reunião, por passagem natural, de documentos oriundos de uma só fonte geradora e, em geral, constituídos em exemplar único, congregados em fundos, divididos em séries. [...] Logo, a biblioteca é o órgão colecionador, que tem a custódia de um acervo fisicamente presente em suas próprias instalações (BELLOTTO, 2014, p.41). 
Se esta divisão for considerada de maneira estrita, seria possível pressupor que a condição de lugar de memória tal como concebido por Pierre Nora (1993) - como aquele que tem por objetivo deter o esquecimento acerca do passado quando inexistem meios de memória que a sustentem no presente -, se aplicaria somente aos arquivos e não às bibliotecas. Por outro lado, a constituição dos acervos das bibliotecas reflete as práticas de seu tempo, sejam elas de leitura - apontando, dessa maneira, para correntes de pensamento de determinados períodos -, sejam de atividades práticas que envolvam os itens bibliográficos. Dessa maneira, os acervos bibliográficos não serão vistos como simples justaposição de itens em estantes, mas enquanto conjunto. Observar os itens da biblioteca de determinado conservatório em certo período permite, por exemplo, constatar os métodos, os livros teóricos e o repertório utilizados no ensino de música em certo período da atividade da instituição. Do mesmo modo que os acervos musicais em geral, o perecimento e o descarte das fontes dificultam tais investigações. Em outras palavras, as bibliotecas também são portadoras de memórias de determinadas coletividades. Essas memórias são capazes de revelar, tal como teorizado por Joël Candau (2011), identidades coletivas que se constituíram e se afirmaram em determinado período. Assim, as bibliotecas também possuem um tipo característico de patrimônio, o qual, no âmbito da Musicologia, se encontra na categoria do patrimônio musical documental, na taxonomia de Antonio Ezquerro Esteban (2016), a mesma dos documentos musicografia. Os itens de interesse para a pesquisa acerca das atividades musicais do passado localizados em bibliotecas estão elencados, aliás, no rol de fontes para o estudo da Musicologia apresentado por Pedro José Gómez González e seus colaboradores (2008).

Acerca dos critérios que têm orientado as definições do patrimônio bibliográfico, escreveu Raphaële Mouren, bibliotecária e especialista em história dos livros e bibliotecas:

As leis e decretos dedicados mais especificamente aos fundos patrimoniais das bibliotecas falam atualmente na noção de documentos "antigos, raros ou preciosos". Adequar-se a apenas um desses critérios é suficiente para colocar o documento no campo de patrimônio. Mas esta definição é muito restritiva: muitos documentos conservados nas coleções patrimoniais não são nem antigas, nem raras, nem preciosas (MOUREN, 2007, p.22, tradução nossa). ${ }^{2}$

É interessante notar que o critério de raridade que antes dificultava o acesso às fontes bibliográficas hoje está, parcialmente superado, já que muitas instituições têm digitalizado seus acervos ${ }^{3}$. Por outro lado, marcas que tornam os itens bibliográficos únicos e que permitem que suas histórias sejam investigadas, tais como as marcas de propriedade, ex-libris, ex-dono, indicação manuscrita da localização topográfica do

\footnotetext{
2 Original: "Les lois et décrets consacrés plus précisément aux fond patrimoniaux des bibliothèques parlent aujourd'hui de documents 'anciens, rares ou précieux'. Répondre à un Seul de ces qualificatifs suffit à faire ranger Le document dans le domaine patrimonial. Mais cette définition est três reductrice: de nombreux documents conservés dans dês collections patrimoniales ne sont effet ni anciens, ni rares, ni précieux".

3 Parte dos itens bibliográficos comentados ao longo deste trabalho foi digitalizada, mas não pela Biblioteca Fran Paxeco. Assim, há de se considerar que os links disponibilizados na bibliografia têm como objetivo possibilitar ao leitor deste artigo o acesso à publicação, com a ressalva das marcas que individualizam os itens analisados, as quais serão eventualmente apresentadas no corpo do texto. Considerando essa ressalva, utilizou-se, nas referências deste trabalho, "Disponivel em" para fonte ou do item individualizado de acervo abordado no trabalho, e "Exemplar disponivel em" para a mesma publicação que integre a coleção de outra biblioteca.
} 
item no acervo e outras marcas de proveniência, pressupõem a digitalização de cada item. Em outras palavras, quando as publicações são disponibilizadas on-line, tem-se as informações da publicação original acrescidas, muitas vezes, das marcas do item disponível naquela biblioteca específica que procedeu à digitalização.

Mouren (2007, p.26-27), porém, foi além dos critérios de antiguidade, raridade e preciosidade - também mencionados na Carta do Conselho Superior de Bibliotecas da França para tratar das coleções nacionais - ao pensar o patrimônio cultural em bibliotecas ou o patrimônio bibliográfico. A autora pôs à prova os limites dos critérios de antiguidade e raridade, destacando a relevância das marcas que individualizam os itens bibliográficos raros, independentemente de qual tenha sido sua edição: uma encadernação especial, marcas de proveniência, ex-libris, ex-dono, ter pertencido a um escritor famoso ou a um bibliófilo. O principal argumento utilizado por Mouren, contudo, dizia respeito não aos itens individuais, mas ao conjunto, ou seja, à coleção ou acervo que ele integra: pode constituir um fundo de interesse regional, o qual pode ser acrescido inclusive de produções recentes, como o CD de um cantor local. Neste sentido, a autora questiona:

A partir do conteúdo atual do fundo patrimonial, da política documental geral da biblioteca, é consideravelmente fácil estabelecer prioridades para conservação e aquisição e eliminar dessas reflexões obras antigas, é claro, mas que não somos particularmente chamados a guardar.

O bibliotecário, considerando essas coleções compostas e díspares, deve identificar as urgências e fazer escolhas em sua ação limitada. A prioridade de conservação e manutenção não está necessariamente vinculada à idade dos documentos: assim, se mantivermos uma pequena coleção de livros religiosos do século XVIII amplamente utilizados e um conjunto de brochuras regionais raras ou até únicas da segunda metade do século $\mathrm{XX}$, quais serão as prioridades para a conservação e os cuidados? (MOUREN, 2007, p.22, tradução nossa). ${ }^{4}$

A resposta a este questionamento perpassa necessariamente a preservação de uma memória coletiva local, que integra ou legitima, em última análise, a identidade coletiva dessa coletividade. No Brasil, a Biblioteca Nacional (2012) empreendeu considerável esforço ao desenvolver um Guia do Patrimônio Bibliográfico Nacional de Acervo Raro. Tal empreitada revela, contudo, limitações, justamente por desconsiderar tais identidades locais e a integralidade dos acervos, mas tendo em primeiro plano a antiguidade dos itens. Ademais, o procedimento para a elaboração do Guia não pressupôs a pesquisa in loco, mas a manifestação das próprias bibliotecas locais. A pesquisa de campo em bibliotecas tem revelado, em diversas situações, que os responsáveis pelos acervos nem sempre têm a necessária formação e o adequado preparo para lidar com itens bibliográficos raros. Ademais, como é comum ocorrer com documentos musicográficos, muitas vezes há confusão entre o ano de composição da obra - no caso, da elaboração do

\footnotetext{
$4 \quad$ Original: "À partir du contenu actuel du fonds patrimonial, de la politique documentaire globale de la bibliothèque, il est assez aisé d'établir des priorités de conservation et d'acquisition, et d'éliminer de ses réflexions des ouvrages anciens, certes, mais qu'on n'a pas particulièrement vocation à garder. Le bibliothécaire, considérant ces collections composites et disparates, doit identifier des urgences, faire des choix dans son action limitée. La priorité de conservation et d'entretien n'est pas forcément liée à l'âge des documents: ainsi, si l'on conserve un petit fonds de livres religieux du XVIII siècle très répandus et un ensemble de brochures régionales rares voire uniques de la deuxième moitié du XX siècle, quelles seront les priorités de conservation et de soins ?".
} 
manuscrito ou da primeira impressão - e a data daquele documento ou item específico: do mesmo modo que uma cópia de uma obra de Bach produzida na década de 1970 pode ser erroneamente atribuída ao século XVIII, uma edição recente de Shakespeare pode ser erroneamente datada do século XVI ou XVII. Focado na datação dos itens por séculos, o Guia não apresenta os principais assuntos das coleções. Esse fator de limitação é amplificado pelo fato de parte das bibliotecas brasileiras não terem seus catálogos disponíveis on-line. É este, parcialmente, o caso da Seção de Obras Raras da Biblioteca Fran Paxeco, do Grêmio Literário e Recreativo Português do Pará, tema deste trabalho: embora esteja disponível on-line um catálogo geral da coleção de 1893 - que constitui uma relevante fonte para o estudo de seu percurso (CATALOGO DA..., 1893) - e tenha havido um esforço por parte de bibliotecários na década de 1980 para catalogar essas obras anteriores ao século XIX (ABUD; MOTA; SANTIAGO, 1985; ABUD et al., 1985a; 1985b), esse catálogo estava disponível para consulta local, e não para o acesso remoto. Atualmente, entretanto, tem sido desenvolvido um projeto para o restauro, conservação preventiva, catalogação e difusão desse acervo.

A Biblioteca Fran Paxeco faz parte da estrutura Grêmio Literário e Recreativo Português do Pará desde sua fundação, em 1867, como Gabinete Português de Leitura. A criação do Grêmio se deu, portanto, em um momento histórico em que as sociedades de mútuos socorros de imigrantes eram crescentes em todo do Brasil, bem como aquelas voltadas à promoção de sua cultura. Após a Independência, diversas associações lusitanas foram criadas, dentre as quais, o Real Gabinete Português de Leitura, no Rio de Janeiro, fundado em 1837, e a Sociedade Portuguesa de Beneficência, em 1840. No Pará, é possível citar a Liga Portuguesa de Repatriação, o Grêmio Lusitano, a Câmara Portuguesa de Comércio e Indústria, o Centro Republicano Português, o Luso Sport Club e a Associação Protetora Musical Luís de Camões, todos extintos, bem como aquelas ainda atuantes: a Associação de Socorros Mútuos "Vasco da Gama" e a Real Tuna Luso Caixeral - atualmente, Real Tuna Luso Brasileira -, voltada inicialmente às atividades musicais ${ }^{5}$ e hoje, às desportivas (BRITO, 1994, p.18).

Para além do Gabinete Português de Leitura do Pará, em diversas outras cidades foram estabelecidos gabinetes de leitura, tais como cidades como Cametá (1877), Marapanim (1873) e Óbidos $(1878)^{6}$, bem como "salas de leitura que se criavam nas várias associações beneficentes políticas e culturais" (NOBRE, 2009, p.92). Esta crescente valorização das práticas de leitura na sociedade é indício de uma mudança ampla na sociedade, ou, mais especificamente, em parte dela, que poderia se dedicar a tais práticas. Neste sentido, o Gabinete de Leitura parecia integrar um grande movimento de morigeração cultural:

\footnotetext{
5 Considerando a intensa atividade musical da instituição no passado, projeta-se a possibilidade de realização de pesquisa documental in loco na mesma em momento oportuno.

6 A pesquisa de campo nas cidades de Óbidos e Cametá não revelou a existência de instituições que tenham sucedido tais gabinetes, tampouco a incorporação de seus acervos pelas bibliotecas municipais. Foi realizada também pesquisa no Grêmio Lítero Recreativo Português do Maranhão, em São Luís. Seu acervo é integrado por obras mais recentes do que as observadas no Pará, além de ser consideravelmente menor.
} 
O gabinete reuniu, em seu seio, portugueses e paraenses. Pode-se dizer que, praticamente, toda a comunidade portuguesa estava agrupada nessa instituição e com ela toda a comunidade letrada da cidade, porquanto, coube a ele o papel de civilizador e de assumir a acepção estabelecida por SHAPOCHNIK em seu estudo sobre o Gabinete Português de Leitura do Rio de Janeiro.

Numa Belém oitocentista repleta de várias vozes sociais, emanadas da cidade em um processo crescente de urbanização, mudanças extraordinárias se efetivavam, à medida que se mesclavam culturas sob os olhares de influências variadas. (NOBRE, 2009, p.19).

Ademais, o crescente movimento de incentivo à leitura ou desta como prática pública e civilizatória aponta também para a necessidade de abastecimento de livros, para coleções que sugerem os principais interesses de pesquisa daquele tempo, mas também para a constituição ou afirmação de identidades por meio da seleção das obras. Diante dessas constatações, deram origem ao presente trabalho os seguintes questionamentos: qual tem sido o papel das bibliotecas na preservação das memórias musicais no Brasil? Quais os itens bibliográficos de interesse para o estudo da música no acervo da Seção de Obras Raras da Biblioteca Fran Paxeco do Grêmio Literário e Recreativo Português do Pará? Há indícios de que esses itens tenham tido relação com práticas musicais locais ao tempo de sua produção ou derivam de uma ação colecionista posterior? No caso da segunda hipótese, é possível identificar uma intencionalidade nesse processo? Para responder a tais questões, foi empreendida pesquisa de campo em acervos e bibliotecas de diversas regiões do Brasil, bem como pesquisa a trabalhos acadêmicos cujas fontes de pesquisa se conservem em acervos de bibliotecas. Foi realizada pesquisa de campo também em Lisboa, uma vez que parte dos itens bibliográficos analisados possui marcas de proveniência que remetem à capital portuguesa. A análise dos dados se baseia nos já mencionados referenciais acerca da relação entre memória, lugares e identidades (NORA, 1993; CANDAU, 2011) e do patrimônio em bibliotecas (MOUREN, 2007). Recorreu-se ainda a Cataldo e Loureiro (2019), que se dedicaram ao estudo das proveniências e dos objetos que integram acervos ou à biografia dos objetos. Segundo o autor e a autora,

[...] gostaríamos de propor a ideia do livro como objeto também no campo da Biblioteconomia como uma forma de analisar esse documento como suporte de memórias que guardam em si falas e trajetórias. Para esse pensamento, lançamos mão dos estudos sobre "Marcas de Proveniência Bibliográfica". Essas marcas são indícios que podem colaborar para a construção de uma narrativa histórica de determinado exemplar. A base para a compreensão das marcas de proveniência bibliográfica assenta-se em David Pearson (1998; 2019), que é muito enfático sobre a necessidade um [sic] estudo sério das bibliotecas privadas, sua origem, formação e desenvolvimento, pois há muito a apreender destes resultados. Para ele, essas marcas não estão associadas apenas à origem ou ao proprietário, mas também a aspectos que evidenciam o uso do exemplar de um livro. (CATALDO; LOUREIRO, 2019, p.11).

Tendo em vista tais referenciais, serão analisadas, no terceiro item desse trabalho, marcas de proveniência dos itens que compõem a coleção especial - uma coleção dentro da coleção maior, que é a da biblioteca -, denominada Seção de Obras Raras da 
Biblioteca Fran Paxeco. Contudo, para responder ao primeiro problema formulado, a questão das bibliotecas enquanto possuidoras de itens de interesse musical para a pesquisa histórica tem lugar na primeira parte deste artigo. Em seguida, passa-se a um olhar mais amplo sobre o Grêmio Literário e Recreativo Português do Pará, para a coleção especial e para alguns itens específicos, cuja análise, a exemplo do que se procederá na última parte do trabalho, também terá suas marcas de proveniência comentadas.

\section{O lugar das bibliotecas na preservação das memórias musicais no Brasil}

A atuação colecionista em relação aos documentos musicográficos por parte de diversos atores foi responsável por legar ao presente acervos musicais sistematizados. As razões que desencadearam tais coleções podem ter sido as mais diversas: a percepção do risco de perecimento de documentos ante a situação econômica, o desinteresse ou desconhecimento por seus custodiadores, a busca pela afirmação de uma identidade musical local, dentre outras. No rol das grandes coleções, algumas poderiam ser aqui citadas. Na região Norte, a coleção Vicente Salles é hoje custodiada pela Biblioteca do Museu da UFPA. No Nordeste, merecem destaque os recolhimentos realizados pelos padres João Mohana e Jaime Diniz. O acervo João Mohana é hoje custodiado pelo Arquivo Público do Estado do Maranhão, ao passo que o fruto do trabalho de Diniz se encontra em parte no Instituto Ricardo Brennand, em Recife, e em parte na Fundação Gregório de Mattos, em Salvador. A coleção empreendida pelo músico e também padre José Penalva se encontra hoje, juntamente com seu arquivo pessoal, no Museu Claretiano de Curitiba. No Sudeste, a coleção Curt Lange recolhida ao Museu da Inconfidência de Ouro Preto é muito provavelmente a mais expressiva. Localizada também em Minas Gerais, a coleção levada a termo por incentivo de Dom Oscar de Oliveira, terceiro arcebispo de Mariana, é uma das que integram o acervo do Museu da Música de Mariana.

Além dessas grandes coleções, é necessário citar ainda os arquivos eclesiásticos que recolhem partituras, como o da Cúria Metropolitana de São Paulo ou do Cabido da Arquidiocese de São Sebastião do Rio de Janeiro. Há ainda instituições de pesquisa ligadas direta ou indiretamente à Igreja Católica, tais como o Laboratório de Conservação e Restauração Reitor Eugênio Veiga (LEV), da Universidade Católica de Salvador, fundado a partir de uma parceria da universidade com a Arquidiocese de Salvador, e o Instituto de Pesquisas e Estudos Históricos do Brasil Central (IPEHBC), ligado à Pontifícia Universidade Católica de Goiás, e que sucedeu o Centro Goiano de Cultura, cuja fundação remete às iniciativas da Arquidiocese de Goiânia. Enquanto o Laboratório Eugênio Veiga conserva em seu acervo versões digitalizadas de livros de Paixões do século XIX, no IPEHBC, razoável quantidade de música religiosa escrita, sobretudo, para formação de bandas é conservada.

No âmbito do catolicismo, as bibliotecas de faculdades e universidades confessionais também preservam interessantes coleções de itens bibliográficos - e, por vezes, documentais - de interesse para a pesquisa histórica em música. Um interessante exemplo é a biblioteca do Instituto de Estudos Superiores do Maranhão/Faculdade Ca- 
tólica (lesma), que recolhe o acervo de parte do seminário da Arquidiocese de São Luís. Já em Minas Gerais, a biblioteca do Santuário do Caraça, na cidade de Catas Altas da Noruega, guarda considerável acervo de documentos musicográficos relativos à atuação da Congregação da Missão, dos padres e irmãos lazaristas ou vicentinos, que foram responsáveis pela administração de muitos seminários católicos na segunda metade do século XIX e primeira metade do XX. Em Juiz de Fora (MG), a Biblioteca Redentorista preserva os vestígios dos seminários da Congregação do Santíssimo Redentor, que tem sido responsável pela administração de grandes santuários no país, a exemplo de Aparecida do Norte. As duas congregações têm presença relativamente recente no Brasil, mas ainda assim guardam interessantes acervos.

Dentre as congregações com presença mais antiga no país, um item bibliográfico merece particular destaque, por possivelmente ter alguma ligação com as práticas locais à época de sua produção7. Trata-se de um exemplar datado de 1620 do Processionarivm monasticvm ivxta consvetvdinem Monachorum Nigrorum Ordinis S. P. N. Benedicti Regnotum Portugaliae (PROCESSIONARIVM, 1620) ou, em tradução livre, Processionário monástico de acordo com os costumes dos monges negros da ordem de nosso Santo Pai Bento do reino de Portugal (Fig. 1). A distinção entre os beneditinos negros e beneditinos brancos se faz em razão da cor de seu hábito: os primeiros são os monges da Ordem de São Bento (O.S.B.), que ocupam a Arquiabadia de São Sebastião da Bahia desde sua fundação, como primeiro mosteiro beneditino do Brasil, ao passo que os monges brancos são da Ordem Cisterciense da Comum Observância (O. Cist.) e da Estrita Observância (O.C.S.O.). Assim, resta clara a ligação entre esse item bibliográfico e a ordem à qual se destina, reforçando a hipótese de sua relação com as práticas musicais de função religiosa locais no século XVII.

\footnotetext{
7 Embora pareça ser a hipótese mais provável, não há indícios exaustivos para tal afirmação. Algumas marcas de proveniência apontam para a presença do livro na biblioteca do mosteiro no início do século XX: um carimbo do "Archivum Archicoenobii Brasiliensis Bahiae" e um ex-libris de Dom José Endres, monge beneditino e historiador atuante no início do século XX no mosteiro da Bahia. Por outro lado, há de se ter em conta o provável impacto, sobre os acervos das livrarias das casas religiosas no Brasil, da supressão de ordens religiosas na gestão de Dom José I, no século XVIII, e da proibição dos noviciados, por Dom Pedro II, em 1855, que causou considerável diminuição no número de religiosos no país, a ponto de ter sido necessária uma restauração dessas ordens a partir da vinda de monges e frades de províncias alemãs e de outras regiões da Europa em fins do século XIX.
} 


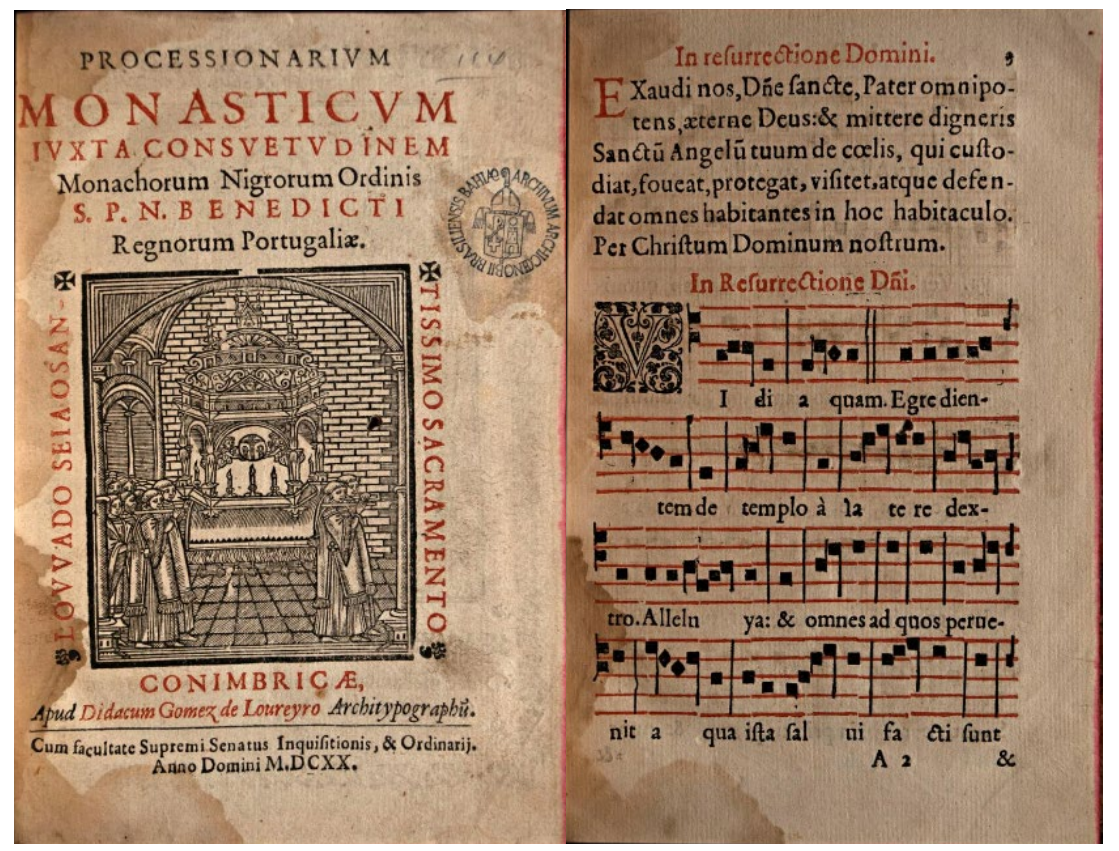

Fig. 1: Detalhes da folha de rosto e da primeira página de música do manual de procissões dos beneditinos, disponibilizado em formato digital na internet pelo Arquicenóbio da Bahia (PROCESSIONARIVM MONASTICVM, 1620).

O exemplo das bibliotecas católicas revela, dessa maneira, como os acervos de bibliotecas podem revelar práticas de leitura e até mesmo práticas musicais baseadas em música escrita. Ademais, as coleções bibliográficas testemunham a própria produção impressa de fontes de interesse para o estudo da história da produção, ensino e das práticas de música.

No âmbito das bibliotecas públicas, deve ser citada inicialmente a Coleção de Manuscritos Musicais de Ernesto Nazareth, recolhida à Biblioteca Nacional, que foi reconhecida pelo Programa Memória do Mundo da Unesco. Para além dessa coleção, é possível citar a vasta coleção de documentos musicográficos e sonoros recolhidos à Divisão de Música e Arquivo Sonoro (Dimas/BN), dentre as quais, a Coleção Thereza Christina Maria, coleção especial constituída de itens que pertenceram às imperatrizes D. Leopoldina e D. Thereza Christina.

Para além dos itens que integram as bibliotecas no presente, a pesquisa aos catálogos das livrarias extintas - segundo Castagna (2006), a paleoarquivologia - constitui eficiente fonte para o conhecimento dos acervos no passado, revelando hábitos de leituras, interesses e possíveis usos musicais dos itens a elas recolhidas. Para além dessa via, marcas de proveniência também são úteis em investigações com tal propósito. Neste sentido, é possível citar um carimbo da "Biblioteca Real" na folha de rosto do Rituale Sacri, Regalis ac Militaris Ordinis B. V. Mariæ de Mercede Redemptionis Captivorum, ad usum Fratrum Ejusdem Ordinis in Congregatione Magni Paraenfi..., o "Ritual da Ordem Sagrada, Real e Militar da Beata Virgem Maria das Mercês para a Redenção dos Cativos para o uso dos irmãos dessa mesma ordem na congregação do Grão-Pará", de 1780 (GABY, 2018, p.40). Adquirido por Vicente Salles em Portugal, esse único exemplar conhecido - que atualmente é custodiado por sua viúva - traz um carimbo "Biblioteca 
Real"8, permitindo que se descubra parte da história do item bibliográfico. Foi também em uma biblioteca que André Gaby (2019) localizou outro item bibliográfico raro ligado aos frades mercedários do Pará: na Seção de Obras Raras da Biblioteca da Faculdade de Direito da Universidade de São Paulo se encontra um manual sacro contendo todos os sacramentos administrados aos enfermos, nos rituais de exéquias e pelo sufrágio das almas para o uso dos religiosos do Grão-Pará. Semelhantemente ao Rituale, o Manuale dos mercedários é o único exemplar conhecido da obra. Mais do que o uso do item bibliográfico em determinada prática musical, nestes casos, sua presença em acervos de bibliotecas atesta a existência de tais obras. Os dois volumes são, portanto, livros raros no sentido mais estrito do termo, já que "livros raros são, principalmente, livros únicos, o que inclui os manuscritos, desenhos e livros impressos mantidos em uma única cópia ou em poucas cópias" (MOUREN, 2007, p.26, tradução nossa). ${ }^{9}$

Outro item único de interesse para o estudo da música foi localizado na biblioteca particular de D. Pedro Gastão de Orleans e Bragança, em Petrópolis (RJ). Em 2005, Alberto Ikeda e Paulo Castagna fizeram o registro fotográfico de Muzico e Moderno Systema para Solfejar sem Confuzão, escrito pelo pernambucano Luís Álvares Pinto, em 1776, que se tornou posteriormente o tema da investigação doutoral de Alexandre Röhl (2016).

Passando de coleções mais amplas relacionadas à história do Brasil ao âmbito estadual, seria possível citar o caso da biblioteca do estado do Maranhão. No Acervo de Obras Raras da Biblioteca Pública Benedito Leite se encontram Principios elementares de musica, e Noções de musica, dois livros escolares de autoria dos maranhenses Domingos Thomas Vellez Perdigão e Antonio dos Reis Rayol, datados de 1869 e 1902 , respectivamente (SALOMÃO, 2019). Tais obras não apenas permitem ampliar o conhecimento acerca da história do ensino de música em determinado período da história do Brasil, como também revelam claramente o caráter local desse ensino.

Da Coleção de Obras Raras da Biblioteca Pública Estadual de Minas Gerais, registra-se a presença de um volume do Cantum Ecclesiasticum sistematizado por Filipe de Magalhães (1571-1652), com data de impressão de 1720, pela oficina tipográfica de Antonio Pedrozo Galram, em Lisboa (Fig. 2).

\footnotetext{
8 É interessante notar que não foi grafado "Bibliotheca", mas "Biblioteca", o que possibilita a formulação de hipóteses acerca da datação do carimbo, da procedência do item e de quando ele possivelmente deixou de integrar o acervo.

$9 \quad$ Original: "Les livres rares sont en premier lieu les livres uniques_ce_qui englobe les manuscrits, les dessins, et les livres imprimés conservés en un seul exemplaire ou très peu d'exemplaires".
} 


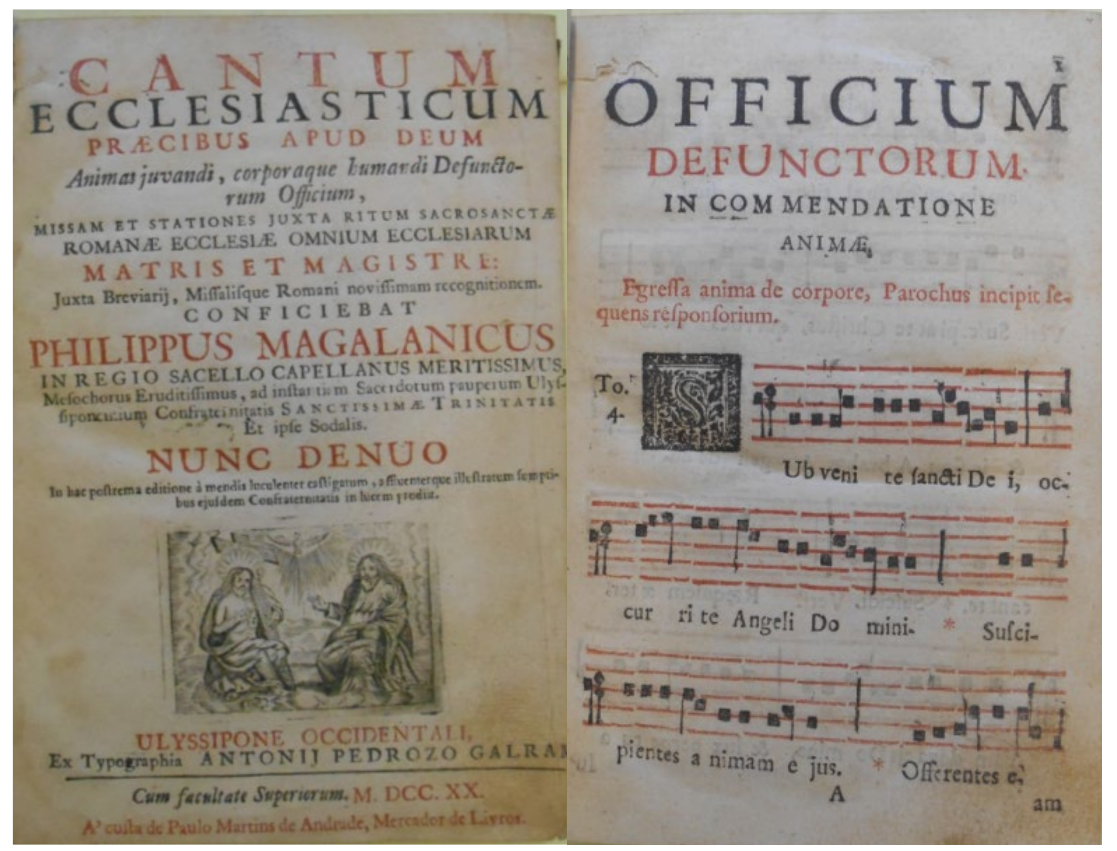

Fig. 2: Detalhes da folha de rosto e primeira página de música do manual Cantum Ecclesiasticum, de Filipe de Magalhães, recolhido à Coleção de Obras Raras da Biblioteca Pública Estadual de Minas Gerais (MAGALANICUS, 1720).

A história do exemplar ainda é pesquisa a ser realizada. Embora inicialmente empreendida quando de sua consulta in loco, não logrou muito êxito. Há de se notar que o verso da folha de rosto traz um carimbo com a indicação "Biblioteca Palacio da Liberdade" e datação manuscrita de 1982. A encadernação do volume seguramente não é do século XVIII e aponta possivelmente para o século XX. Na mesma coleção se encontra ainda o livro Hymnologia Sacra, do padre mestre frei José da Assumpção, agostiniano. O item foi impresso em Lisboa, em 1738.

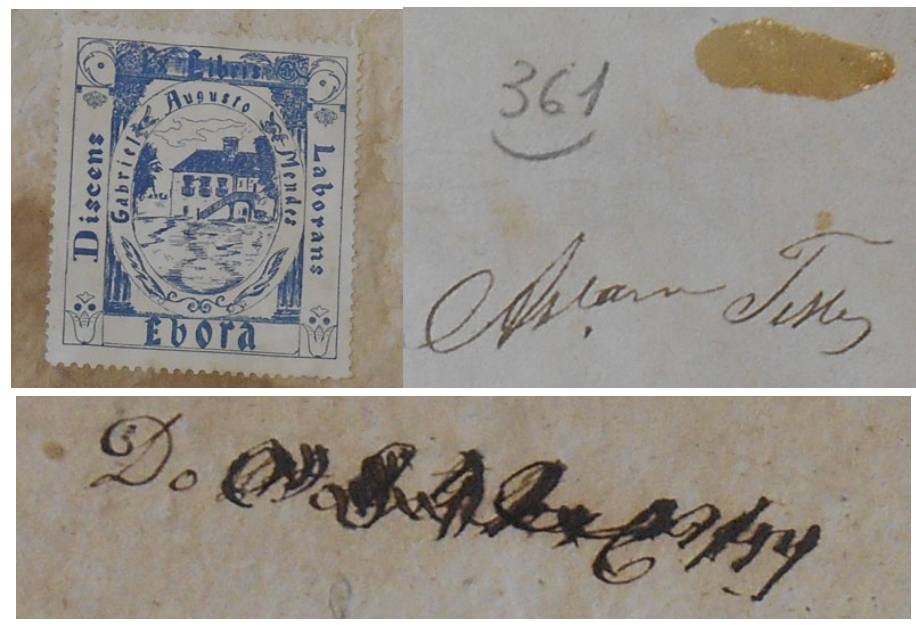

Fig. 3: Detalhes das marcas de propriedade e de proveniência do exemplar de Hymnologia Sacra (ASSUMPÇÃO, 1738), que integra a Coleção de Obras Raras da Biblioteca Pública Estadual de Minas Gerais.

Apesar do título sugestivo, não se trata de obra para uso musical, mas da explanação de todos os hinos do tempo do Breviário Romano e de alguns santos, que deveria ser utilizado pelos pregadores para a "compozição, e ornato dos feus Sermoens" (AS- 
SUMPÇÃO, 1738, f.1). Foi trazido a este trabalho, contudo, com o objetivo de se observarem as marcas de proveniência e propriedade, tais como o ex-libris de Gabriel Augusto Mendes, editor da cidade de Évora, uma marca de propriedade manuscrita e a possível indicação rasurada da localização topográfica do volume na livraria da casa religiosa onde se encontrava inicialmente, em muito semelhante às marcas de proveniência do acervo do Grêmio Literário e Recreativo do Pará, como se verá adiante.

\section{O acervo da Biblioteca Fran Paxeco e um olhar sobre a coleção especial}

A Biblioteca Fran Paxeco está localizada no terceiro andar da Sede Social do Grêmio Literário e Recreativo Português, na Rua Senador Manuel Barata, no bairro da Campina, em Belém do Pará, próxima à centenária Igreja de Sant'Anna. A consulta ao acervo corrente é autorizada ante a prévia identificação na portaria instituição. Já o acervo da coleção especial, de itens bibliográficos dos séculos XVI a XVIII, tem passado por um processo de restauro e conservação dos itens, o que tem inviabilizado sua consulta ${ }^{10}$. A coleção nem sempre esteve localizada nesse endereço. Inicialmente, o Gabinete Português de Leitura era sediado na Rua Belém, número 1, no primeiro andar, passando, ainda no ano de fundação, a funcionar em uma sede provisória localizada no Largo da Independência, hoje Praça Dom Pedro II. Apesar das mudanças de endereço, os itens bibliográficos mais antigos se conservaram. Ainda no tocante à conservação, é importante ressaltar que suas estantes de madeira de lei parecem ter tido papel fundamental na preservação dos itens, uma vez que o tipo de madeira escolhido evitou a infestação por agentes biológicos, tais como cupins e brocas (Fig. 4).

\footnotetext{
10 Recomenda-se aos interessados, sobretudo àqueles que se encontram fora do estado do Pará, o contato prévio com a instituição a fim
} de tomarem conhecimento das políticas de acesso aos consulentes aplicadas à coleção especial. 


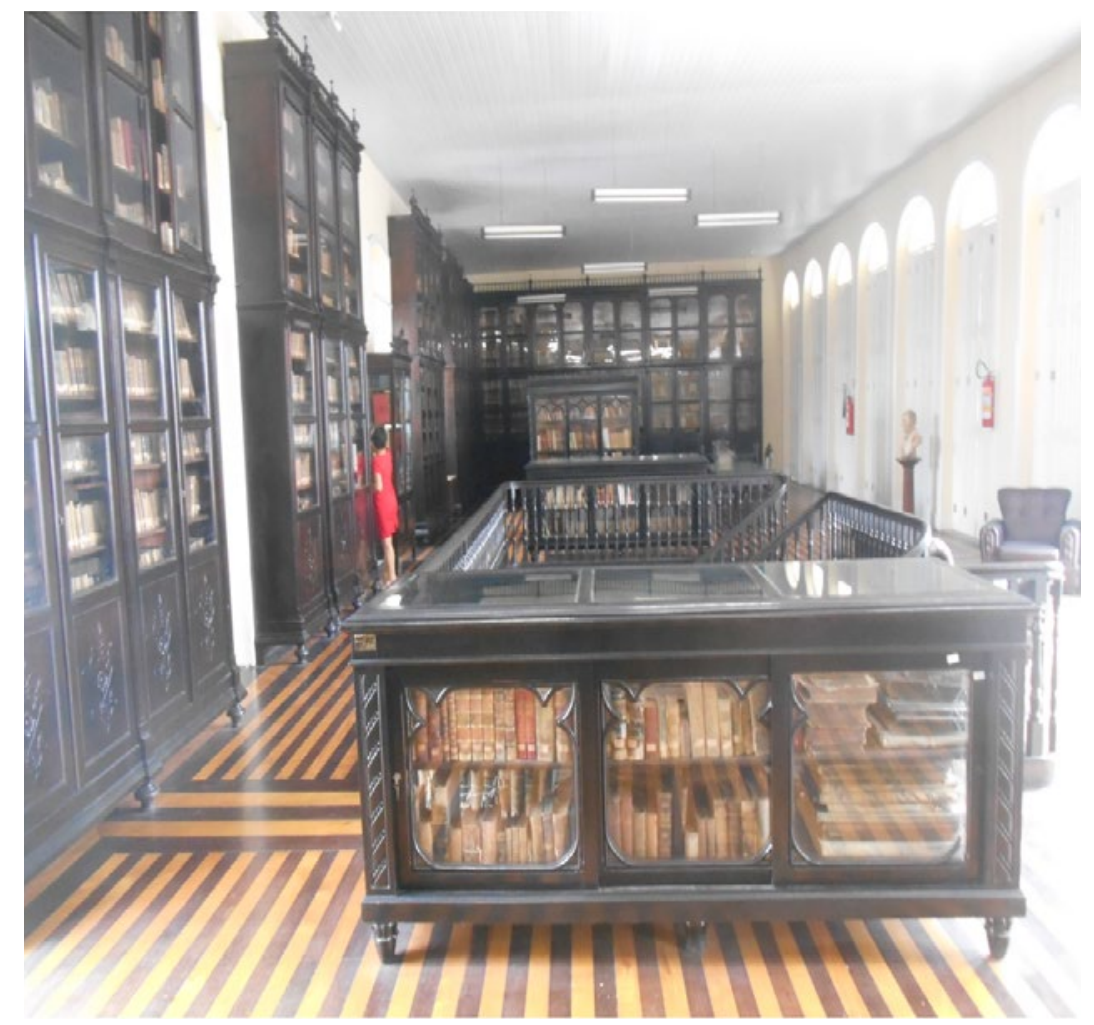

Fig. 4: Visão Geral da Biblioteca Fran Paxeco, do Grêmio Literário e Recreativo Português em 2017. Fonte: Fotografia nossa.

O acervo da biblioteca conta hoje com mais de 40 mil itens, dos quais, 1.165 somente com obras de Camilo Castelo Branco, o que posiciona sua Coleção Camiliana entre as mais expressivas do mundo. No acervo que se poderia dizer corrente ou de consulta local estão livros dos séculos XIX e XX. Na prateleira dedicada à música, chamam a atenção dez itens de Biographie des Musiciens, de François-Joseph Fétis - volumes 1 a 8 e suplementos dos volumes 1 e 2 -, impressos no século XIX. Do mesmo autor, conserva-se no acervo um exemplar da segunda edição do Traité complet de La Théorie et La Pratique de L'Harmonie, impresso em 1879. Igualmente interessante é um Graduale Romanum impresso em 1862 com a marca de propriedade do Grêmio de 1871, apenas nove anos após a impressão (Fig. 5).

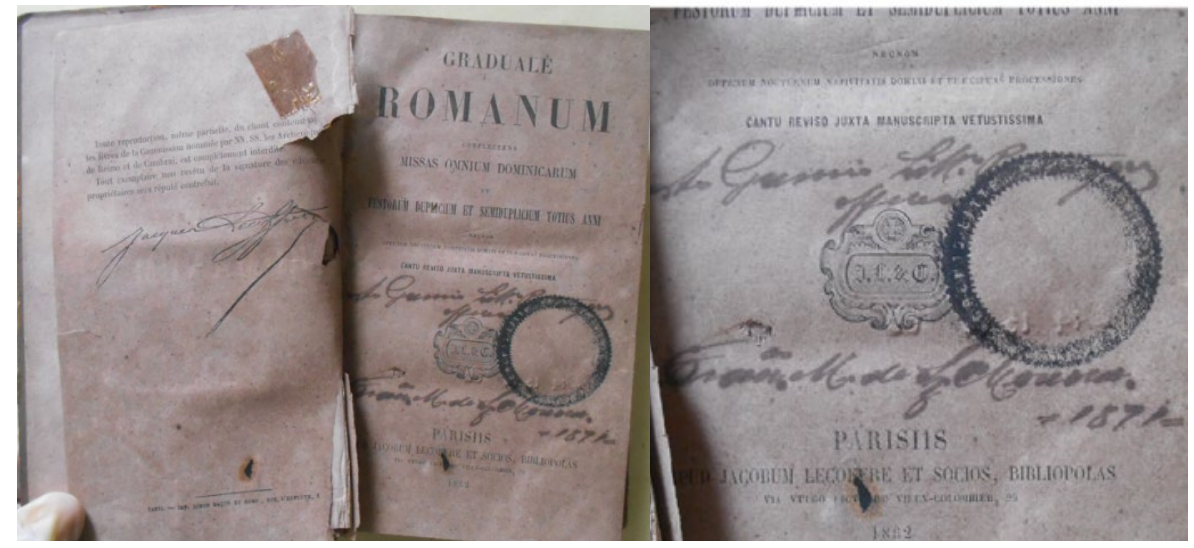

Fig. 5: Graduale Romanum (1862) e detalhe das marcas de propriedade: inicação manuscrita "do Gremio Littº Portuguez" datada de 1871 e carimbo úmido posterior. 
Há ainda uma coletânea de partituras para órgão, para uso em serviços religiosos, Le Service Paroissial: 50 morceaux pour orgue, de Charles Ferlus ([1876]), com uma anotação manuscrita que sugere ter pertencido a uma coleção anterior, embora não seja possível identificá-la (Fig. 6).

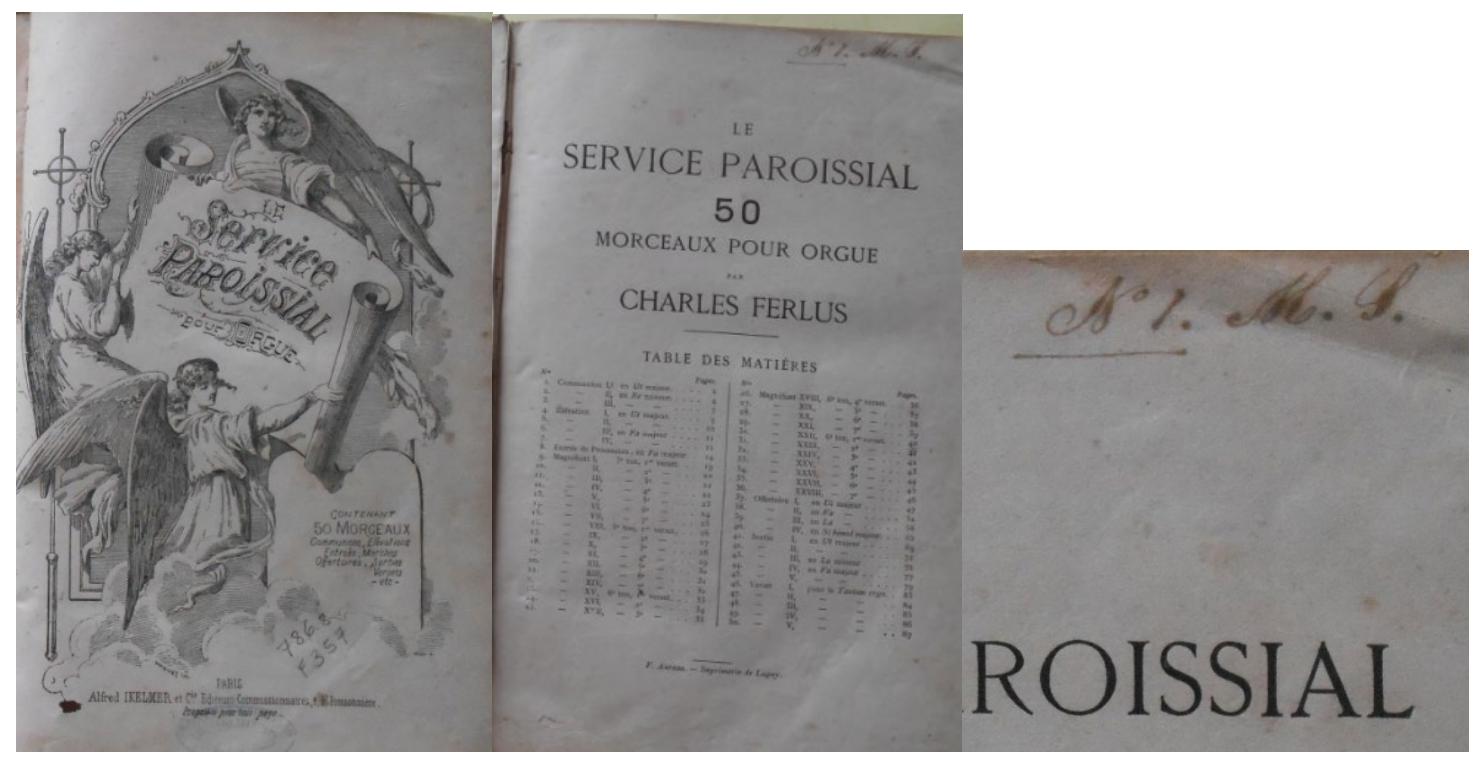

Fig. 6: Le Service Paroissial, de Charles Ferlus, do acervo da Biblioteca Fran Paxeco e o detalhe da anotação manuscrita em seu sumário, sugerindo ser o primeiro item de uma possível coleção.

Se a presença de autores franceses, quer na obra de Fétis, quer na coletânea de obras para órgão, aponta para as práticas musicais do século XIX e um teórico de produção expressiva para o período, dois volumes de Os Musicos Portuguezes, de Joaquim de Vasconcellos (1870), revelam o caráter identitário da instituição que o adquiriu para sua coleção (Fig. 7). Aspecto a ser notado em tais itens é sua encadernação, em capa dura de cor cinza, que revela um padrão que se repete em diversos itens da Seção de Obras Raras e até mesmo em outros acervos da cidade de Belém. As características físicas da encadernação e os padrões tipográficos das lombadas dos livros apontam possivelmente para sua aquisição das mãos do alfarrabista António Maria Pereira, ainda no século XIX. As razões que motivaram sua escolha como principal fornecedor de livros para o Gabinete de Leitura são somente conjecturadas, uma vez que, segundo Valéria Augusti (2009, p.2), os documentos relativos às reuniões da diretoria desapareceram, não permitindo atestar com certeza as razões. Tais documentos certamente apontariam com maior clareza os critérios para a seleção das obras. 


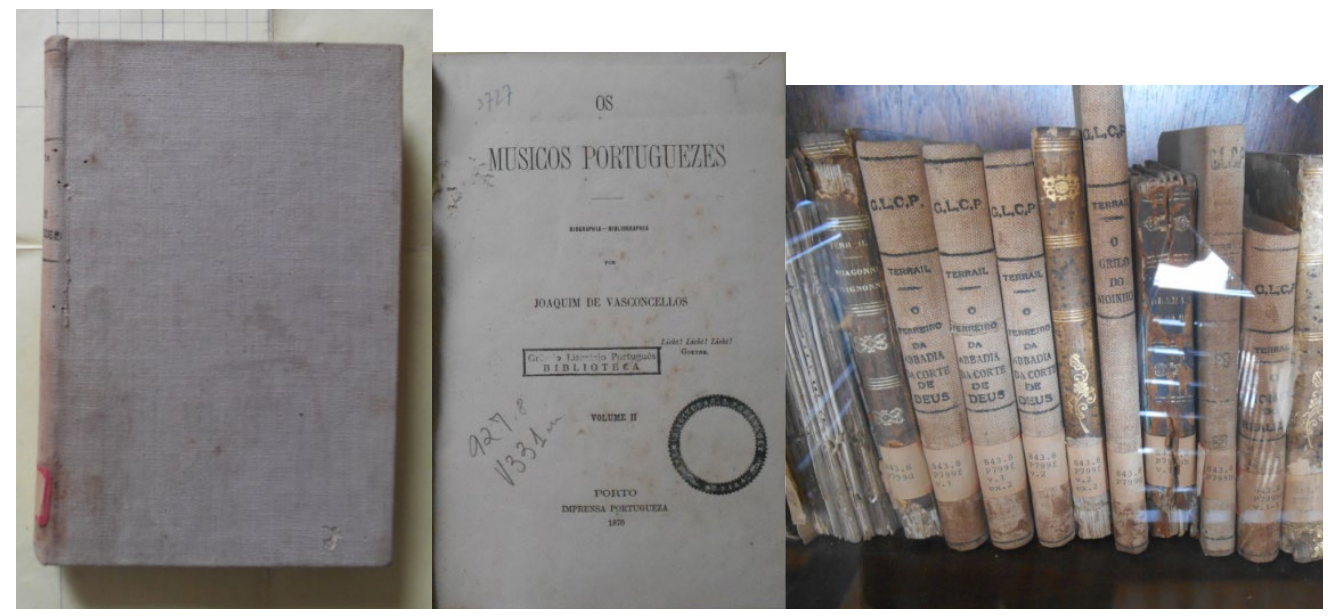

Fig. 7: Encadernação e folha de rosto de Os Musicos Portuguezes, de Joaquim de Vasconcellos (1870), na Biblioteca Fran Paxeco. Detalhe do padrão de encadernação nas estantes.

Diferentemente da classificação dos itens no acervo corrente - com códigos próprios ao sistema de bibliotecas -, a coleção especial de livros antigos e raros tem seus itens classificados pela datação e disposição nas estantes de acordo com este critério. Para tanto, haviam sido colocados marcadores que não agrediam a encadernação ou as páginas dos livros, conforme se vê na coleção de leis e decretos do Concílio de Trento, que contém inclusive o Index dos livros proibidos pela Igreja Católica à época (Fig. 8).

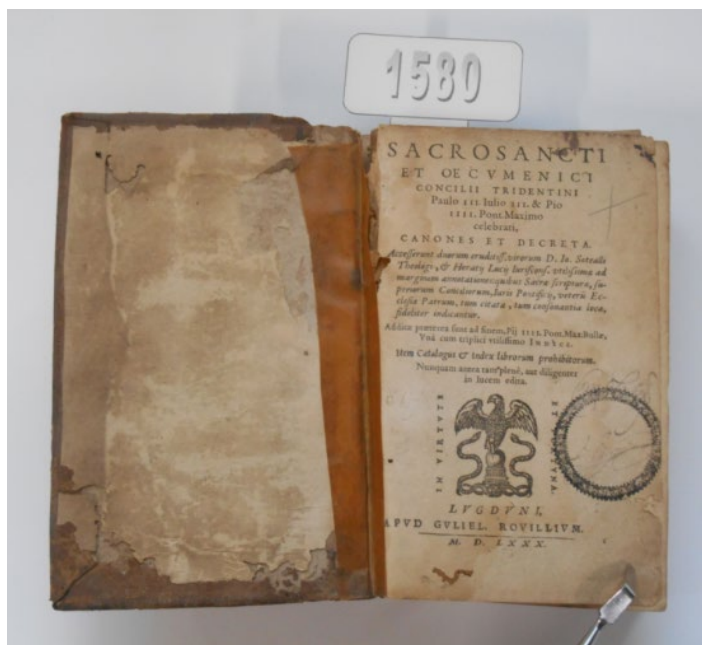

Fig. 8: Exemplo de marcador de datação em Sacrosancti et Oecumenici Concilii Tridentini (1580), na Seção de Obras Raras da Biblioteca Fran Paxeco.

A respeito das obras raras, o critério é evidentemente aplicável a uma encadernação possivelmente do século XVIII, de manuscritos e impressos sobre diversos temas, dentre os quais, diversos tratados e acordos comerciais entre Portugal e outros países. Em um dos manuscritos leem-se menções à regulamentação da censura prévia de publicações. Nas anotações é feita referência ao Título 102 do Livro V das Ordenações Filipinas, de 1603 (MONTENEGRO et al., 2008, p.108), e são mencionados os reformadores protestantes Calvino e Lutero (Fig. 9). 


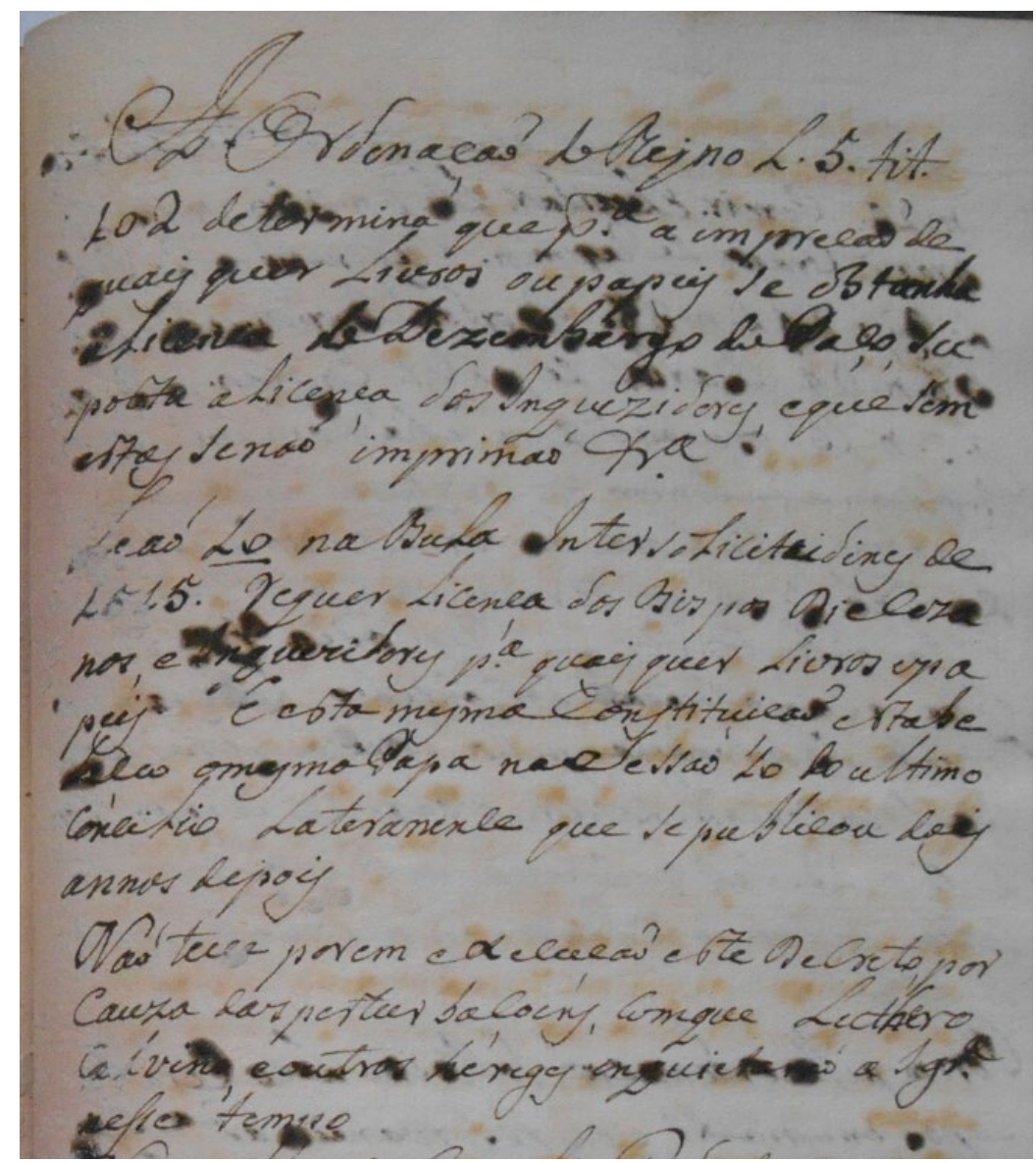

Fig. 9: Detalhes de conjunto de fólios manuscritos encadernados em uma coletânea sobre temas diversos, na Seção de Obras Raras da Biblioteca Fran Paxeco (OBRAS VARIAS, [17--]).

\section{Um impresso também merece destaque quanto ao critério de raridade:}

O volume de Chronographia y Repertorio de los Tiempos da biblioteca é o segundo a ser encontrado fora da Espanha, aponta a especialista em preservação de patrimônio Ethel Soares. Existem só outros sete exemplares no mundo. Publicado em 1585, o livro do astrônomo espanhol Francisco Vicente de Tornamira trata de temas como a criação do universo e o movimento dos planetas e as constelações (ALVES; ORTEGA, 2018).

A seleção das obras mais antigas, que aparentemente não mais seriam utilizadas para a finalidade para as quais foram criadas - a preparação de sermões ou o ensino de teoria musical, por exemplo -, parece remeter à busca pela constituição de um acervo fundador que afirme uma identidade. Algumas hipóteses postuladas por Valéria Augusti para a escolha do livreiro parecem se aplicar também à seleção do acervo:

A primeira delas, por certo, diz respeito à nacionalidade da instituição. $O$ fato de ter sido fundada por portugueses provavelmente consistiu em fator preponderante na escolha de um parceiro de mesma nacionalidade, residente em Portugal. [...] $O$ interesse em divulgar as obras dos conterrâneos recém-publicadas em Portugal - desejo este manifesto em inúmeras ocasiões pela diretoria do Grêmio - por certo também justifica essa escolha (AUGUSTI, 2009, p.2). 
Esta identidade seria, entretanto, exclusivamente lusitana? Ou seria possível pensá-la como tendo sido luso-amazônida? A segunda hipótese parece mais coerente. Para atestá-la, podem ser estabelecidos paralelos entre alguns itens bibliográficos e a história social e religiosa da Amazônia. A presença holandesa que marcou o processo inicial da dominação da Amazônia pelos europeus pode ser relacionada ao que foi descrito na década de 1980 como "Coleção de Tratados em Alemão Gótico: 1578-1701", mas que são, na verdade, tratados em holandês - alguns celebrados com Portugal - escritos com tipos góticos (Fig. 10).

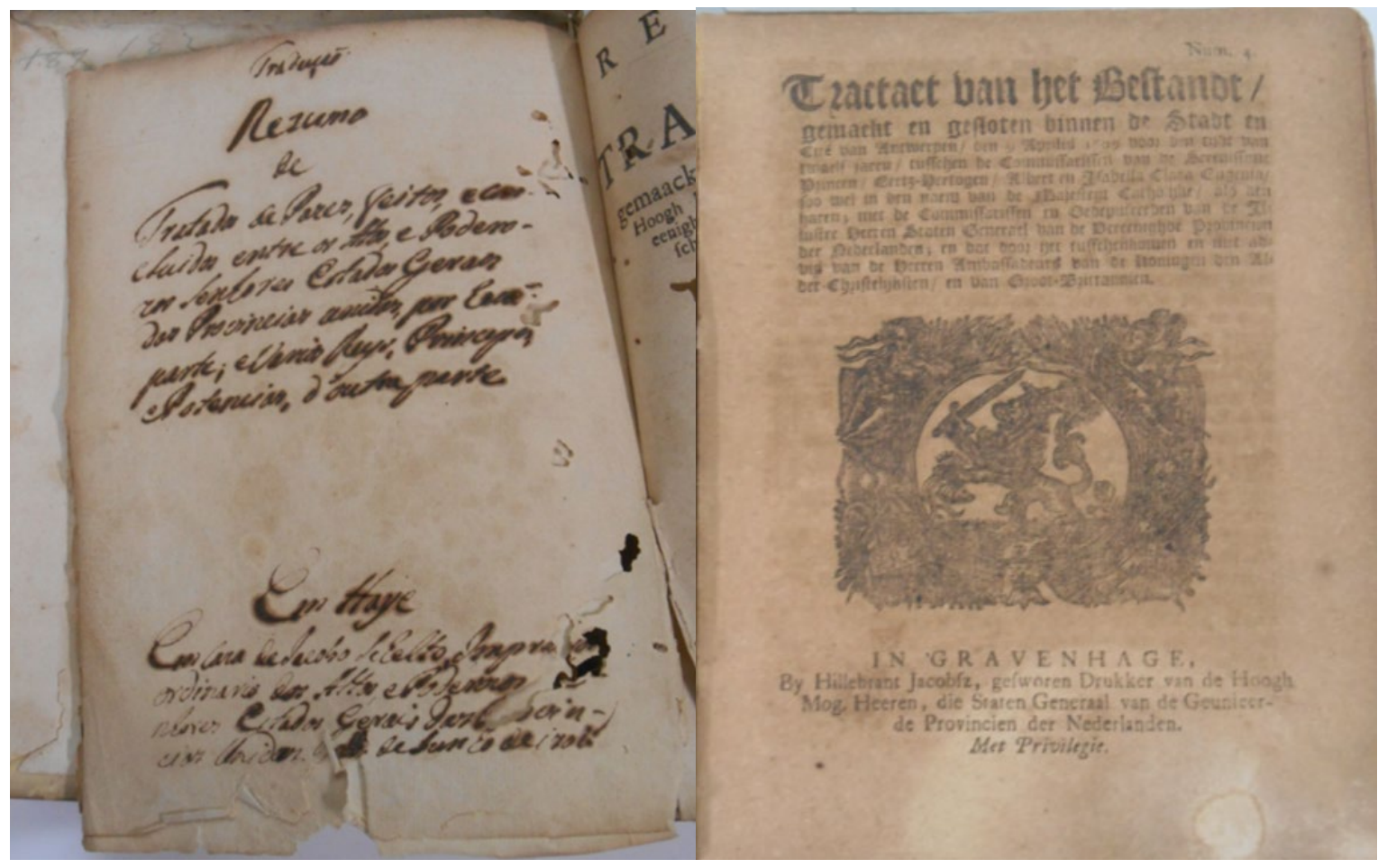

Fig. 10: Índice manuscrito dos tratados e exemplo de tratado em língua holandesa, na Seção de Obras Raras da Biblioteca Fran Paxeco (COLEÇÃO..., [17--]).

Item mais específico acerca da Amazônia é o livro que contém a crônica de viagem do jesuíta Cristóbal de Acuña (1597-1676) traduzida para francês: Relation de La Riviere des Amazones, "sobre a cópia impressa em Paris em 1682" (D'ACUGNA, [1682?]). Ordens religiosas que realizaram missionação também são representadas nas autorias de livros que integram a coleção, tais como diversas obras de jesuítas. Delas, destaca-se Libro del Bien Del Estado Religioso - redigido originalmente em latim e traduzido para espanhol -, do padre Jerónimo Plati, pelo fato de seu exemplar trazer uma marca de proveniência da biblioteca ou livraria de São Francisco de Xabregas ou Convento de Santa Maria de Jesus (Fig. 11). Em pesquisa de campo em Lisboa, não foi constatado acervo remanescente do convento franciscano, no complexo deste antigo convento que hoje abriga o Teatro Ibérico e a Mediateca de Formação Profissional do Instituto do Emprego e Formação Profissional. 

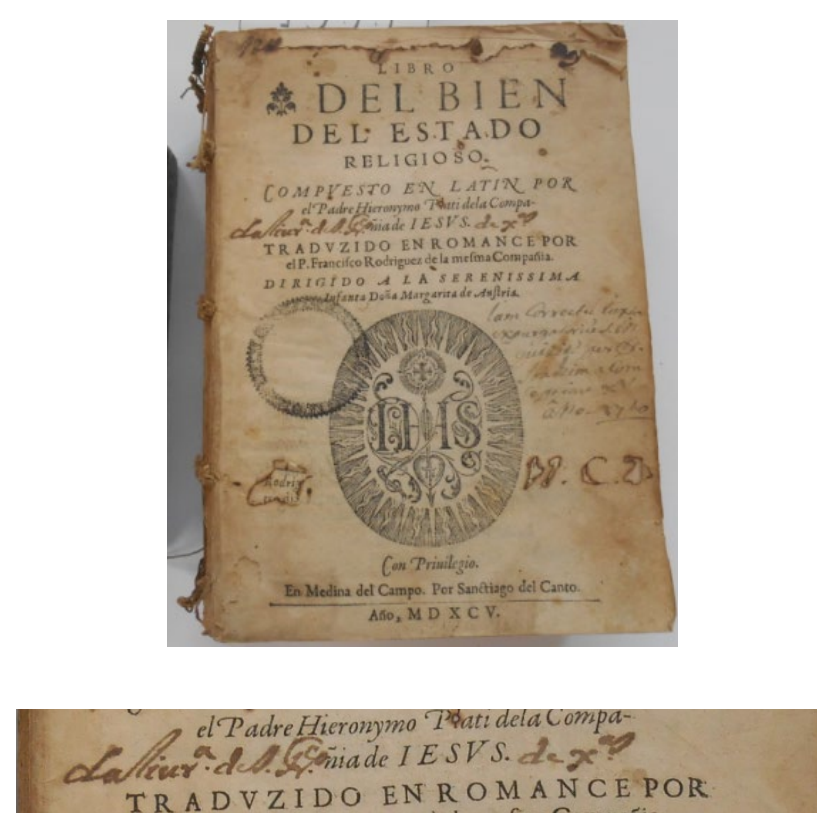

Fig. 11: Folha de rosto de Del Bien Del Estado Religioso, na Seção de Obras Raras da Biblioteca Fran Paxeco, com o detalhe da marca de propriedade "da livr. ${ }^{a}$ de S. Fr.co de X.as" (PLATI, 1595).

Uma possibilidade de prosseguimento da pesquisa dos itens não musicais, mas que excede os limites deste trabalho, é a pesquisa nos catálogos das bibliotecas das casas religiosas que foram extintas quando da Reforma Geral Eclesiástica, que ocorreu em Portugal, em 1834, que extinguiu todos os mosteiros, conventos, hospícios e demais casas religiosas masculinas, deixando sob a direção dos bispos as femininas. Tal pesquisa pode ser realizada nos catálogos manuscritos, disponibilizados em formato digital no site da Biblioteca Nacional de Portugal ou por meio do livro Clavis Bibliothecarum (GIURGEVICH; LEITÃO, 2016), que buscou sistematizar tais instrumentos de pesquisa.

De volta às ordens e congregações religiosas atuantes na Amazônia, uma ordem de presença característica da região Norte é a dos mercedários espanhóis, que poder-se-ia dizer representada pela obra Consideraciones sobre todos los evangelhos, do padre mestre frei Hernando de Sanctiago (1568), religioso da Ordem de Nossa Senhora das Mercês para a Redenção dos Cativos (Fig. 12). O livro, em espanhol, foi impresso em Lisboa, em 1598, ao tempo da União Ibérica (1580-1640). Há ainda obras religiosas do universo da dominação espanhola da América, como é o caso de algumas impressas no México. 


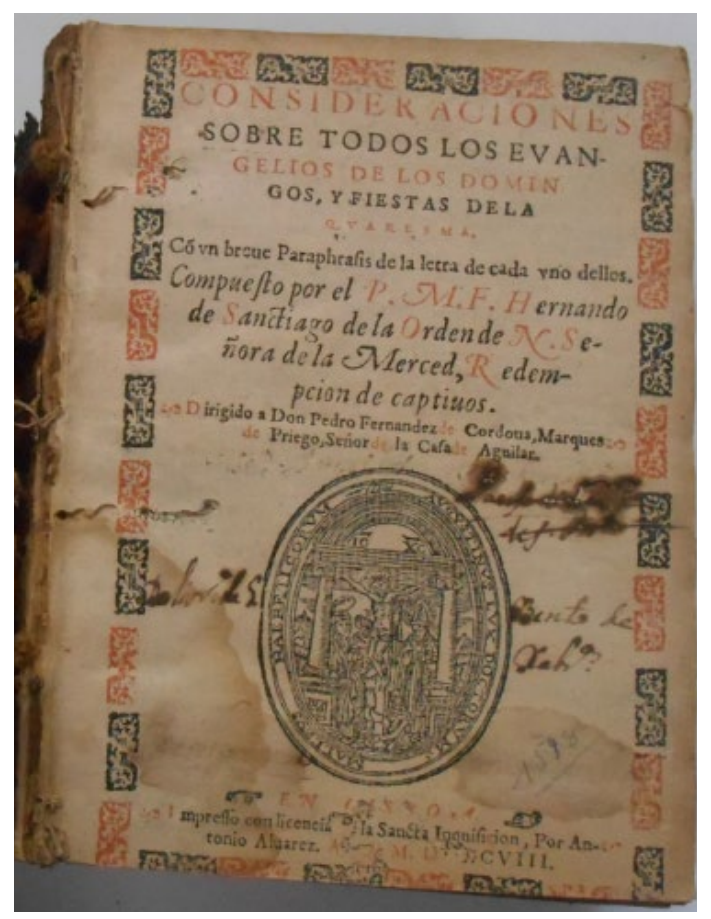

Fig. 12: Folha de rosto de Consideraciones sobre todos los Evangelhos, na Seção de Obras Raras da Biblioteca Fran Paxeco, com o detalhe da marca de propriedade "Da livr. ${ }^{a}$ de S. Bento de X.as" (SANCTIAGO, 1598).

A construção do Convento de São Bento de Xábregas ou Convento do Beato data do século XV e teria servido à Congregação dos Lóios, dos Cônegos Seculares de S. João Baptista ou "Cônegos Azuis". Após uma extensa história que inclui saques, incêndios e outras avarias, o convento passou à iniciativa privada e tem hoje uso empresarial. Em pesquisa de campo, sequer foi possível adentrá-lo. Tal convento poderia não apresentar qualquer relação com a Amazônia não fosse o fato de o primeiro bispo empossado do Maranhão ter sido um cônego secular da Congregação de São João Evangelista11. Note-se que, entre 1679 e 1689, período do bispado de Dom Gregório dos Anjos, o Maranhão era a única diocese da Amazônia, sendo que o Bispado de Belém data de 1719. Já a Ordem da Santíssima Trindade, do bispo Dom Frei José Delgarte, do Maranhão, entre 1716 e 1724, está representada no acervo por um item que possui, inclusive, marca de propriedade (Fig. 13). 


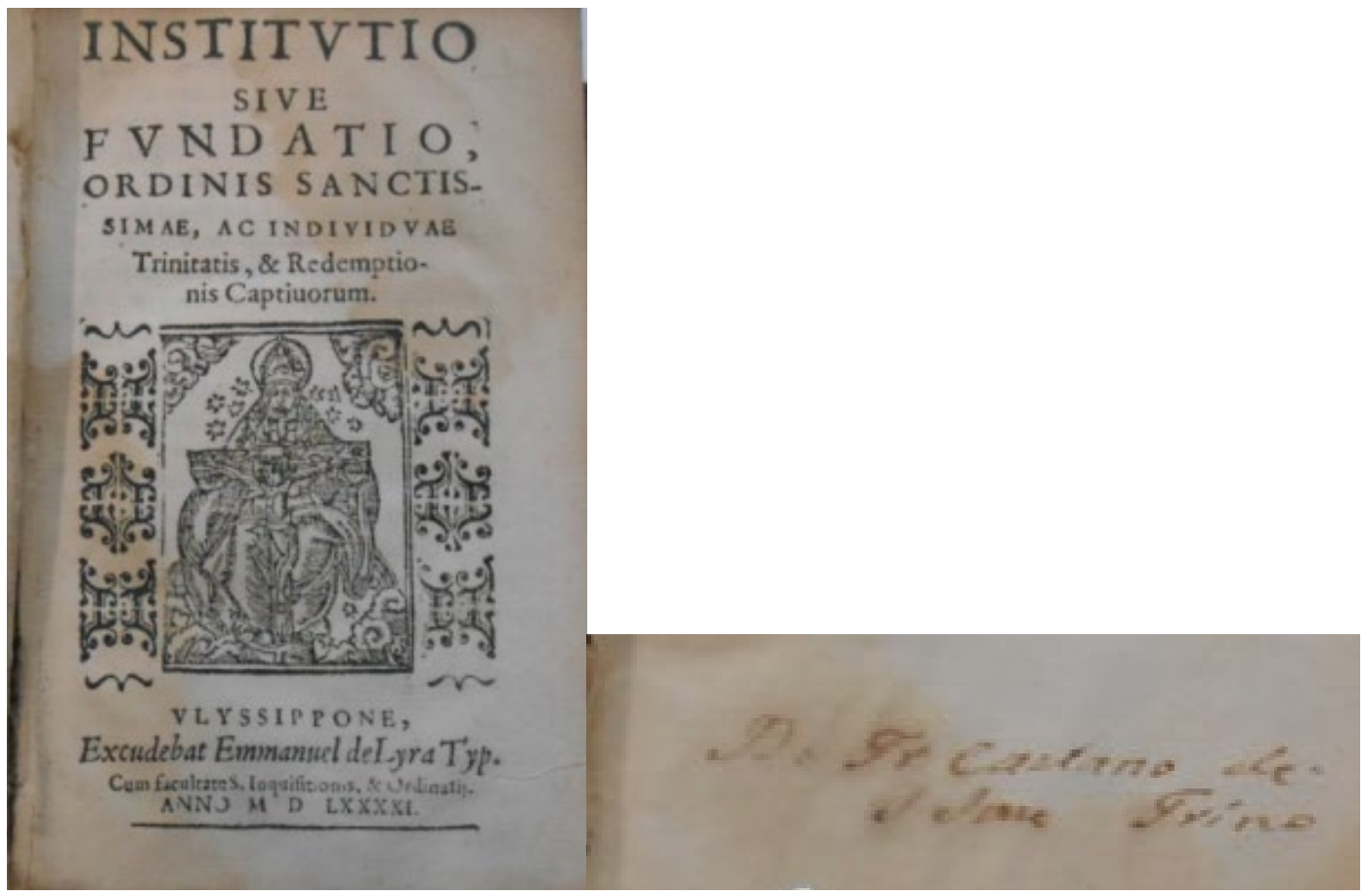

Fig. 13: Folha de rosto de Institutio sive Fundatio Ordinis Sanctissimae, ac individuae Trinitatis \& Redemptionis Captivorum, impresso em Lisboa, na Seção de Obras Raras da Biblioteca Fran Paxeco, com o detalhe da marca de propriedade "Do Fr. Caetano de S.

[San?] [Trind?]"12 (INSTITUTIO..., 1591).

A ordem dos carmelitas, também atuante em toda a Amazônia, do Maranhão ao Alto Rio Negro também está representada no acervo, em um breviário dedicado aos frades e religiosas do Carmelo, impresso em Veneza em 1757. É também de autoria de um carmelita o Tratado de La Inmaculada Concepción de la Virgen Maria N. S., do padre mestre frei Alonso Sobrino. O item tem marca de proveniência da Livraria de Nossa Senhora das Graças de Lisboa, principal casa da ordem dos agostinianos descalços na Península Ibérica. Em pesquisa de campo nessa casa, foi possível localizar ainda um acervo de tamanho considerável, conforme se verá mais adiante. Note-se, na marca de proveniência, a localização topográfica do item na biblioteca: estante, casa (prateleira) e número do livro (Fig. 14).

\footnotetext{
12 A dificuldade na leitura do nome gera dúvida sobre o possuidor do livro. É certo se tratar de um "Frei Caetano", talvez da Santíssima Trindade. Há ainda notícias de um "Frei Caetano de S. Léu", que realizou missões na Bahia, tendo sido citado inclusive por Euclides da Cunha, em Os Sertões, e um Fr. Caetano do Espírito Santo, guardião do convento de Santo Antônio de Ipojuca, em Pernambuco, no século XVIII. A segunda letra da segunda linha se parece mais, contudo, com um "S" caudado do que com um "L". Por outro lado, parece improvável o uso de "Espírito Santo" em latim para a assinatura.
} 


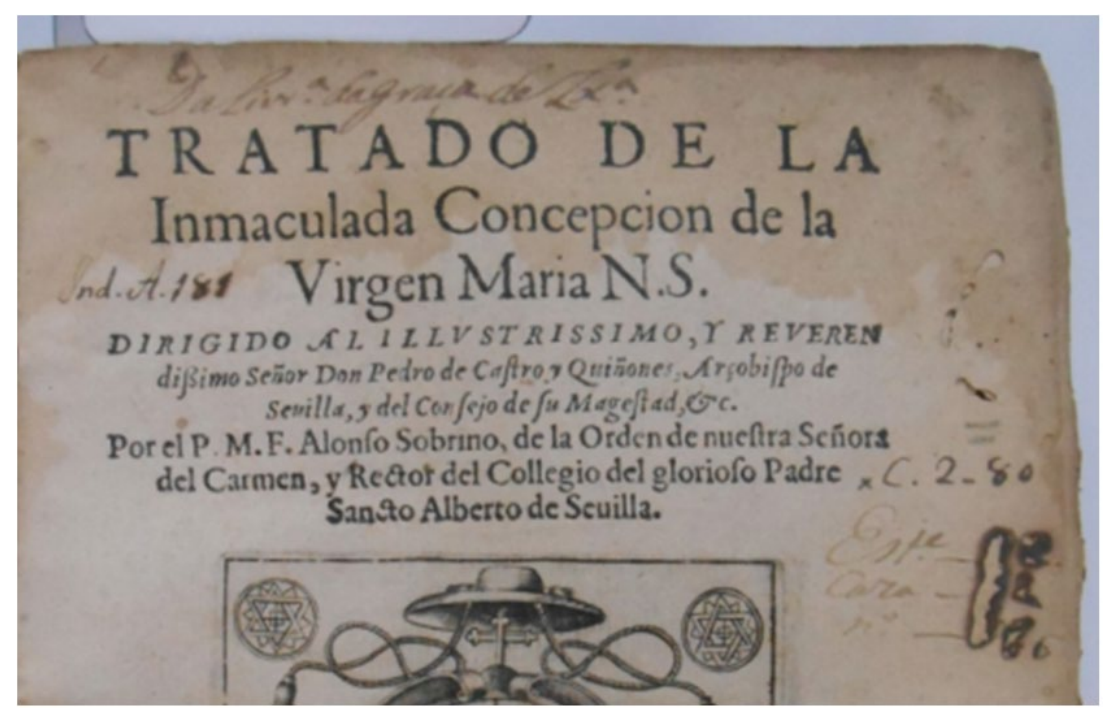

Fig. 14: Detalhe da marca de proveniência na folha de rosto de Tratado de La Inmaculada Concepción de la Virgen Maria N. S. (SOBRINO, 1615), na Seção de Obras Raras da Biblioteca Fran Paxeco:"Da livr. ${ }^{a}$ da Graça de Lx. a | C. 2-80 | Est.e [ilegível] | Caza [ilegível] | n. [ilegível]".

A partir da observação de tais itens, parece clara a busca por uma seleção que não apenas tratasse de Portugal, mas que também reconstituísse, de certo modo, a história da Amazônia.

Finalmente, destaca uma marca de propriedade de "Manoel Marçal da Sylveira" no curioso livro Anatomico Jocoso: que em diversas operaçoens manifefta a ruindade do corpo humano, para emenda do viciofo (ZEFERINO, 1760). O nome do possuidor consta de documentos portugueses da década de 1770, relacionado a Cascais, Portugal, sendo neles tratado como "Reitor" (OLISIPO, 1947, p.21-22). Não há indícios de sua presença no Brasil, o que reforça a hipótese de que a aquisição do volume seja tardia, ao tempo da constituição do acervo do Gabinete Português de Leitura. Feitas tais considerações, passa-se, finalmente, aos itens de interesse musical constantes da Seção de Obras raras da Biblioteca Fran Paxeco.

\section{Fontes musicais e a busca por vestígios de atividades musicais locais}

A Seção de Obras Raras abriga diversos itens que são de interesse para o estudo da música, datados dos séculos XVI ao XVIII. Há escritos que lidam com os textos musicais ou com o modo de fazer música, em grande parte, escritos por teólogos, há um livro de teoria musical e outro sobre o canto gregoriano, um manual de procissões para uso dos agostinianos descalços e, finalmente, coletâneas de libretos de ópera. Para sistematizar a apresentação dos itens será adotada, portanto, essa sequência.

Dos itens que tratam de música ou dos textos que são cantados, o mais antigo é o Psalterium Decachordum, de 1598, com encadernação em pergaminho, possivelmente original. A encadernação é reforçada com pedaços de folhas manuscritas. Trata-se de uma obra de exercícios espirituais, redigida pelo abade cartuxo Jean Michel de Coutances (1535-1600). Uma tradução para o título da obra seria: 
Saltério de dez cordas: no qual se transmite método utilíssimo para o estabelecimento da atenção e devoção às salmodias e orações vocais: para o uso dos vários nomes de Deus, preces e petições fervorosas: aqui são apresentados e explicados, para que sempre e em toda parte os fomente, e as jaculatórias das orações a Deus, não pouco úteis para o progresso no amor divino. (CONSTANTINENSI, 1598, f.1, tradução nossa) $)^{13}$.

Um dos recursos do método de Coutances para que se decorem as orações é muito semelhante, visualmente, à mão de Guido D'Arezzo (992-1050), sistema mnemônico de leitura musical (Fig. 15).

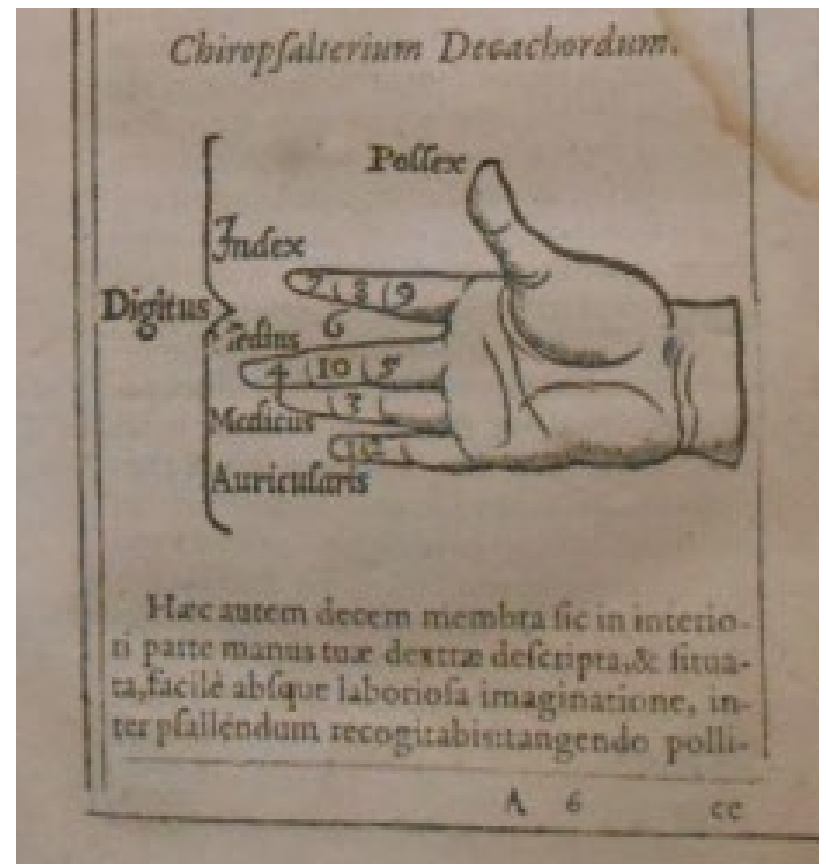

Fig. 15: Detalhe do Chiropsalterium ou a "mão-saltério", em Psalterium Decachordum (CONSTANTINENSI, 1598, p.11), na Seção de Obras Raras da Biblioteca Fran Paxeco.

Igualmente de caráter teológico, mas que versa sobre textos de hinos católicos tais como o Akathistos, à Mãe de Deus - é S. losephi Hymnographi e Mariale, do padre Hipólito Marraccio Luques, clérigo regular da Congregação da Mãe de Deus (LUCENSIS, 1661). Este item e o anterior - o Psalterium - não apresentam marcas de proveniência exaustivas que permitam recobrar suas histórias. $O$ mesmo se pode dizer sobre o Discurso Theologico sobre los Theatros y Comedias de este siglo, do jesuíta Ignacio de Camargo (1650-1722), impresso em Lisboa, em 1690. A obra possibilita um olhar para possíveis práticas musicais de seu tempo na Espanha (CAMARGO, 1690). Não há qualquer indício, entretanto, de seu uso no território amazônico quando de sua produção. O caráter lusitano das obras se revela na seleção: ainda quando escritas em espanhol, muitas foram impressas em Portugal. 
Pouco menos antiga, mas de interesse mais estritamente musical, é a edição do exemplar de Arte minima que com semibreves se prolaçam: trata em tempo breve, os modos da Maxima, \& Longa fciencia da Mufica, do padre Manoel Nunes da Sylva (16401740). Embora este volume não tenha marcas de proveniência, a encadernação em capa cinza sugere que tenha sido adquirido do alfarrabista António Maria Pereira quando da constituição do acervo, no século XIX. Conforme se vê a seguir, semelhante tipo de encadernação é o de Arte do Cantochão, do compositor português Mathias de Sousa Villa-Lobos (1643-1704). Ambas constam do catálogo da biblioteca do Grêmio publicado em fins do século XIX (CATALOGO DA..., 1893).

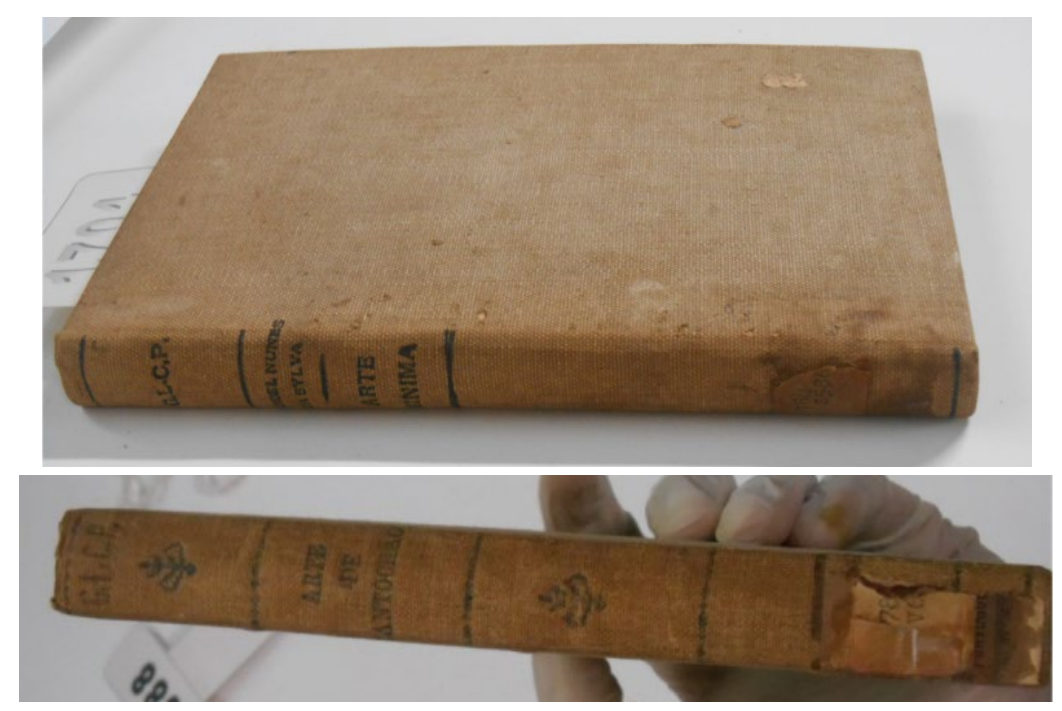

Fig. 16: Detalhe da encadernação de Arte Minima, de Manoel Nunes da Sylva (1704), e da lombada de Arte do Cantochão, de Villa-Lobos (1688), ambos do acervo de obras raras da Biblioteca Fran Paxeco.

Se os exemplares de Arte Minima e Arte do Cantochão têm em comum a ausência de marcas de proveniência - à exceção da encadernação - , um fator que os difere são as marcas de uso. Se o primeiro não aparenta intervenções, o segundo traz, no rodapé da página de erratas, a anotação manuscrita "Efta emmendado dos erros"14. Ao longo de todo o livro há intervenções com tinta ferrogálica com as correções (Fig. 17). Apesar de recorrentes, não há qualquer identificação de quem as teria realizado.

\footnotetext{
14 Aparentemente, tais emendas são a adequação às disposições da errata. Não se descartou, contudo, a hipótese de que alguma possa ter sido realizada para a correção da ortografia ou até mesmo em razão da passagem do sistema hexacórdico ao heptacórdico muito mais tarde. Tal verificação haverá de ser realizada no futuro.
} 


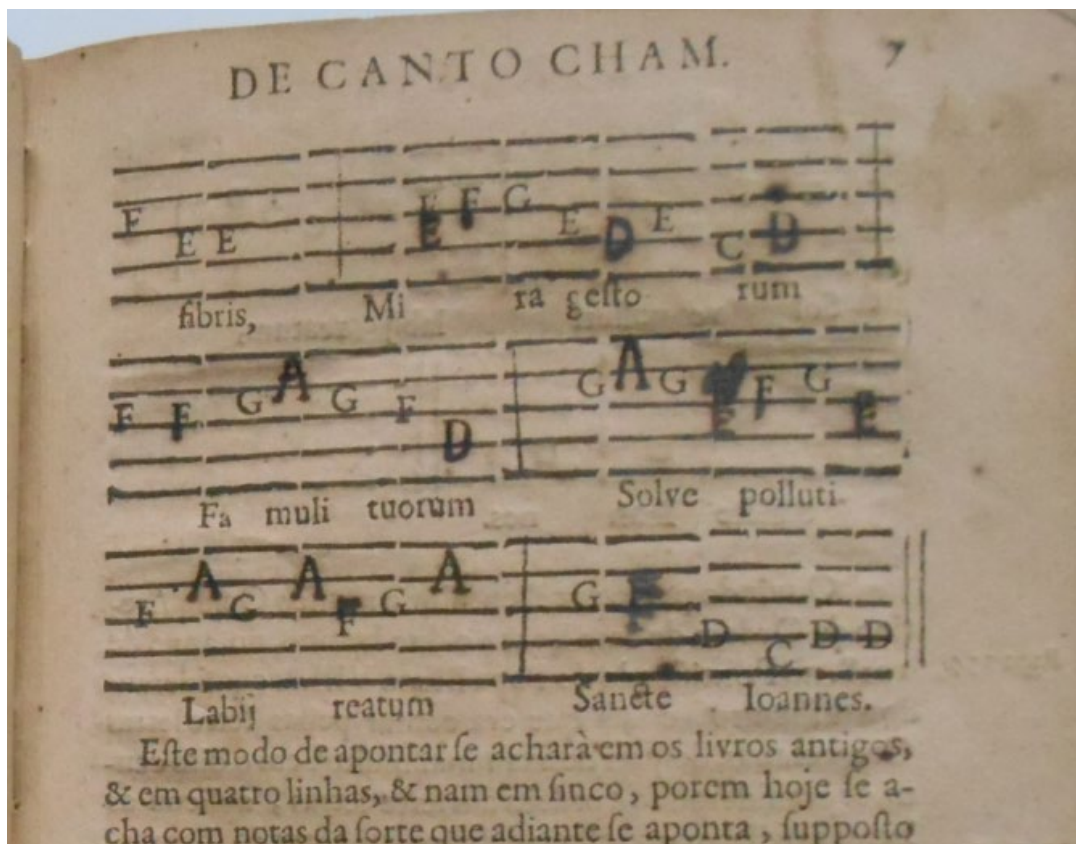

Fig. 17: Detalhe da correção manuscrita no exemplar de Arte do Cantochão, de Villa-Lobos (1688), do acervo de obras raras da Biblioteca Fran Paxeco.

Um Manuale Processionum de 1733 é o item efetivamente musicográfico da coleção. Semelhantemente ao Rituale e ao Manuale mercedários para o uso dos religiosos do convento do Pará que se mencionou anteriormente, o Manuale Processionum também tinha destinatários bastante bem definidos, os agostinianos descalços de Portugal. Já no prefácio da obra lê-se uma saudação aos "irmãos da sagrada religião em nossa família agostiniana do reino lusitano" (MANUALE..., 1733, p.2, tradução nossa) ${ }^{15}$. Por um lado, o possível uso local seria descartado pelo fato de não se ter registro de missionação de agostinianos na Amazônia no século XVIII, por outro, a indicação da proveniência do volume é bastante clara: "N.sa S. Da Graça de Lyx.a" (Fig. 18). A busca em catálogos relativos ao convento (CATALOGO DOS..., 1751; BIBLIOTECA AUGUSTINIANA, 1750) não revelou, entretanto, tal item, sendo possível que este permanecesse no coro, para uso dos religiosos professos e em formação. Em pesquisa de campo, em Lisboa, foi possível ter contato com o acervo remanescente no complexo arquitetônico da antiga casa religiosa agostiniana. Por outro lado, não foi possível obter até o momento o catálogo desse acervo, para então proceder à comparação e, eventualmente, à constatação de existência de itens semelhantes ainda em seu lugar de origem. A hipótese mais provável é que parte do acervo da livraria e do convento de Nossa Senhora da Graça tenha sofrido descaminho quando da Reforma Geral Eclesiástica de 1834, tendo sido posteriormente comercializada por livreiros portugueses na segunda metade do século XIX ${ }^{16}$. 


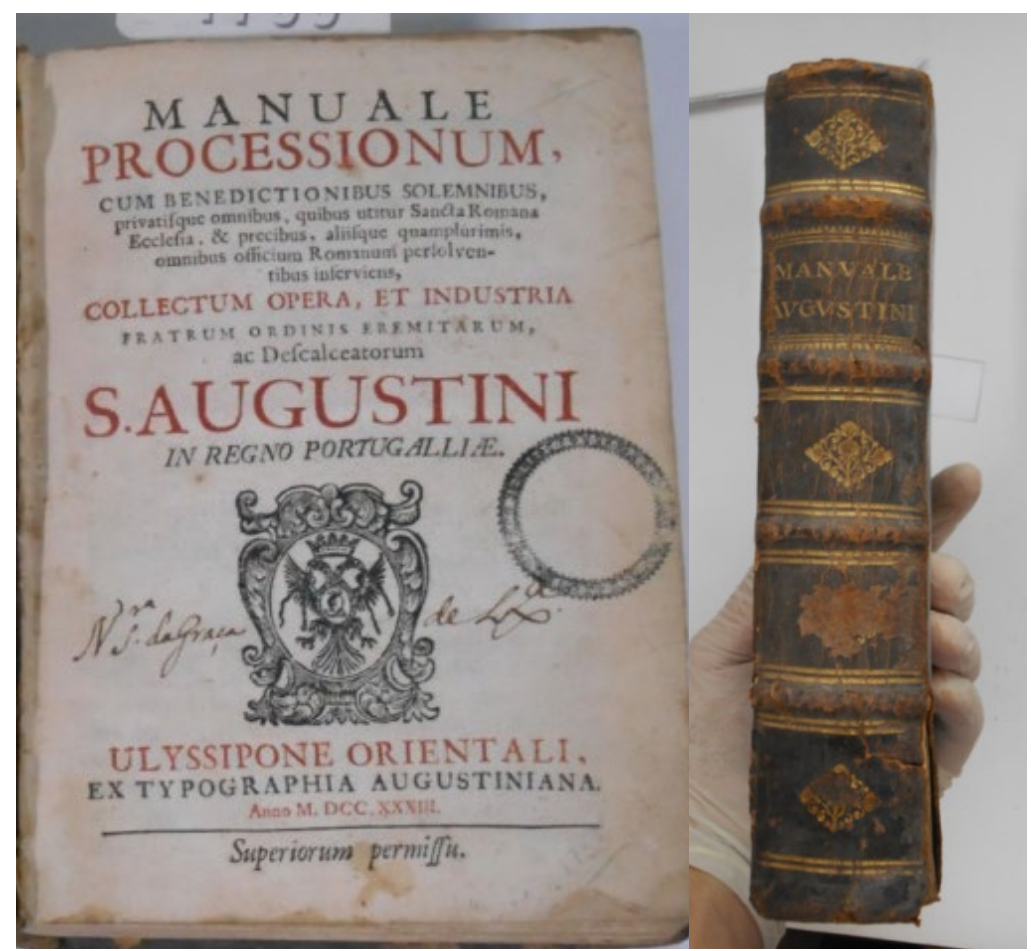

Fig. 18: Folha de rosto e lombada do Manuale Processionum (1733), no acervo de obras raras da Biblioteca Fran Paxeco. Note-se a marca de proveniência: "N.sa S. Da Graça de Lyx.a".

Por fim, uma série de encadernações de libretos de óperas representa a maior amplitude temporal como categoria, estendendo-se as datas de impressão das fontes de fins do século XVI à segunda metade do século XVIII. A primeira a ser mencionada tem na lombada gravado Comedie Varie T. 81, sugerindo integrar uma extensa coleção, que certamente não aparece completa na Seção de Obras Raras, e da qual também não há indícios da biblioteca que a abrigava originalmente. Os títulos contidos nesta encadernação e as respectivas datações constam do quadro que segue.

\begin{tabular}{|l|l|l|}
\hline Título & Autoria & Local e ano \\
\hline I Giochi Troiani: Dramma per Musica & Carlo Sigismondo Capece & Roma, 1688 \\
\hline Il Furto: Comedia & M. Francesco D'Ambra & Venetia, 1596 \\
\hline La Peregrina Costante: Dramma Sacro & Loreto Vittorii & Roma, 1647 \\
\hline Alessandro: Comedia & Alessandro Piccolomini & Venetia, 1596 \\
\hline
\end{tabular}

Quadro 1: Libretos na encadernação Comedie Varie T. 81 ([17--]), com o título, autoria, local e ano de impressão do documento, na sequência em que se encontra na encadernação.

Em outra encadernação, esta sem qualquer inscrição na lombada, há diversos libretos que indicam que foi "opera rappresentati in Mufica" (Quadro 2), todos eles de autoria de Francesco Busenello, impressos em Veneza, na mesma oficina, em 1656, sugerindo que não tenham sido encadernados a posteriori, mas originalmente. 


\begin{tabular}{|l|l|}
\hline Título & Local e ano repr. \\
\hline Delle Hore Ociose & -- \\
\hline Gli Amori D'Apollo e di Dafne & Venetia, 1640 \\
\hline La Didone & Teatro di San Cafciani, 1641 \\
\hline L'Incoronatione di Popea & Teatro Grimano, 1656 \\
\hline La Prosperita Infelice & -- \\
\hline La Statira Principessa di Persia & -- \\
\hline
\end{tabular}

Quadro 2: Encadernação de libretos sem título (BUSENELLO, 1656), com o título, autoria, local e ano de impressão do documento e da representação da obra, na sequência em que se encontra na encadernação.

Há ainda oito tomos de óperas e dramas de autoria de Carlo Goldoni, tais volumes apresentam, contudo, uma conexão menos forte com Portugal do que os três tomos encadernados - possivelmente ainda no século XVIII - sob o título de Opere Varie ([17--]a, [17--]b, [17--]c). Trata-se de libretos de óperas apresentadas em Lisboa, na década de 1770, no Teatro da Rua dos Condes (Fig. 19).

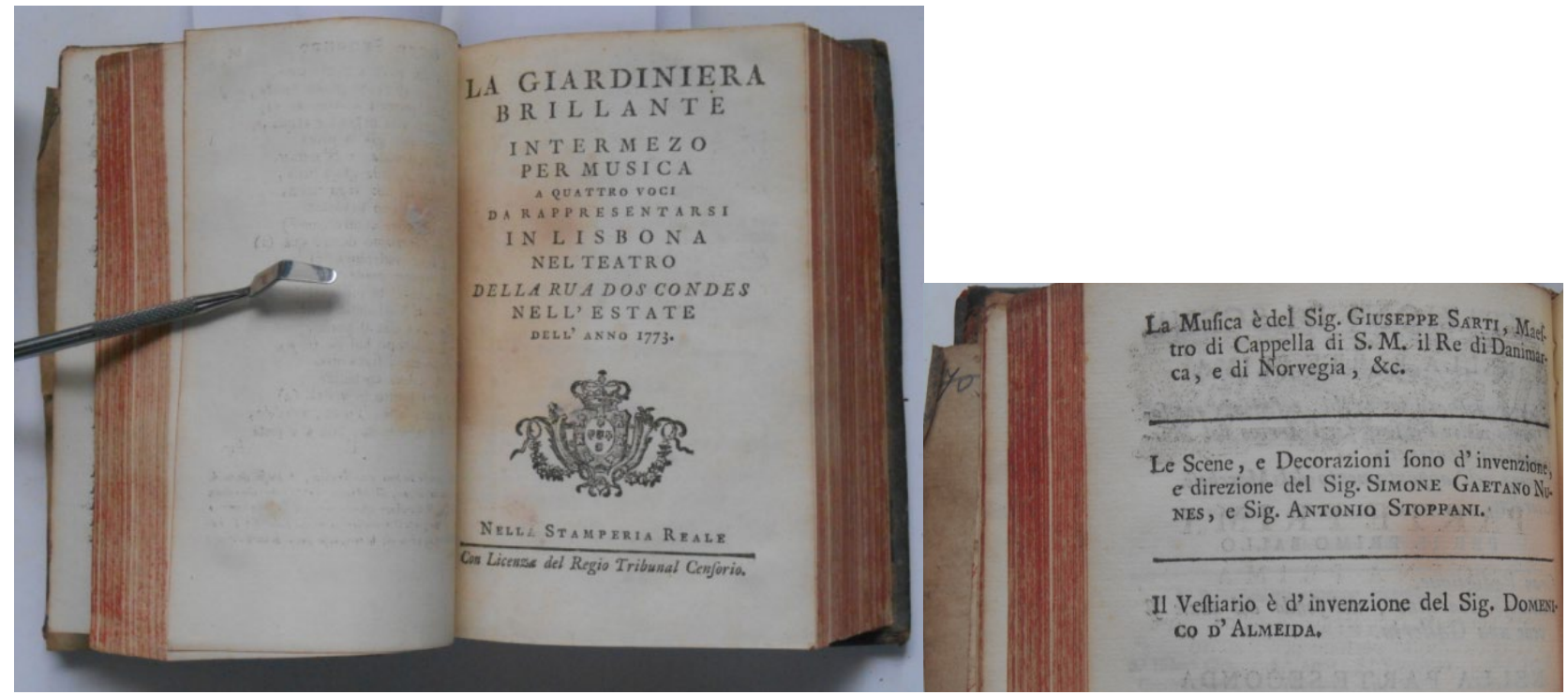

Fig. 19: Exemplo de libreto de obra representada no Teatro da Rua dos Condes, em Lisboa, no segundo volume da encadernação Opere Varie ([17--]b) que integra a coleção especial de obras raras da Biblioteca Fran Paxeco. Note-se a indicação do compositor.

O primeiro volume contém sete representações ocorridas dos anos de 1772 e 1773, ao passo que o segundo, oito, representadas em 1773, e o terceiro, seis, entre 1773 e 1775. Todas as representações dos três volumes ocorreram no Teatro da Rua dos Condes, em Lisboa, à exceção do oratório Ester, em cujo libreto consta apenas que seria cantado em Lisboa, no dia 4 de março de 1774, mas sem indicação do local. A fim de sistematizar o conteúdo das três coletâneas de libretos, foi elaborado o quadro que segue (Quadro 3). 


\begin{tabular}{|c|c|c|}
\hline Título & Compositor & $\begin{array}{l}\text { Ano da } \\
\text { representação }\end{array}$ \\
\hline \multicolumn{3}{|l|}{ TOMO I } \\
\hline Il Disertore: Dramma Giocoso per Musica & Pietro Gugliemi & 1772 \\
\hline L'Anello Incantato: Dramma Giocoso per Musica & Ferdinando Bertoni & 1772 \\
\hline L'Isola di Alcina: Dramma Giocoso per Musica & Giuseppe Gazaniga & 1772 \\
\hline La Locanda: Dramma Giocoso per Musica & Giuseppe Gazaniga & 1772 \\
\hline \multicolumn{3}{|l|}{ L'Anello Incantato (Libreto repetido) } \\
\hline \multicolumn{3}{|l|}{ L'Isola di Alcina (Libreto repetido) } \\
\hline L'Antigono: Dramma per Musica & Francesco di Majo & 1772 \\
\hline La Contessa di Bimbinpoli: Dramma per Musica & Gennaro Asteritta & 1773 \\
\hline La Betulia Liberata: Dramma Sacro & [sem indicação. Mozart?] & 1773 \\
\hline \multicolumn{3}{|l|}{ TOMO II } \\
\hline La Molinarella: Dramma Giocoso per Musica & [Niccolò] Piccini & 1773 \\
\hline $\begin{array}{l}\text { La Finta Semplice o sia Il Tutore Burlato: Dramma } \\
\text { Giocoso }\end{array}$ & Giacomo Monopoli & 1773 \\
\hline $\begin{array}{l}\text { La Giardinera Brillante: Intermezo per Musica a } \\
\text { Quattro Voci }\end{array}$ & Giuseppe Sarti & 1773 \\
\hline $\begin{array}{l}\text { Il Barone di Roca Antica: Intermezo per Musica a } \\
\text { Quattro Voci }\end{array}$ & Carlo Franchi & 1773 \\
\hline La Finte Gemelle: Dramma Giocoso per Musica & Niccolò Piccini & 1773 \\
\hline $\begin{array}{l}\text { ll Matrimonio per Concorso: Dramma Giocoso per } \\
\text { Musica }\end{array}$ & Felice Alessandri & 1773 \\
\hline La Sposa Fedele: Dramma Giocoso per Musica & Pietro Guglielmi & 1773 \\
\hline Il Cidde: Dramma per Musica & Antonio Sacchini & 1773 \\
\hline \multicolumn{3}{|l|}{ TOMO III } \\
\hline $\begin{array}{l}\text { L'Isola d'Amore: Intermezo per Musica a Quattro } \\
\text { Voci }\end{array}$ & Antonio Sacchini & 1774 \\
\hline L'Amore senza Malizia: Dramma Giocoso per Musica & Bernardino Ottani & 1774 \\
\hline L'Orfane Svizzere: Dramma Giocoso per Musica & Antonio Boroni & 1773 \\
\hline Calandrano: Dramma Giocoso per Musica & Giuseppe Gazaniga & 1774 \\
\hline Il Geloso: Dramma Giocoso per Musica & Alberto Giuseppe & 1775 \\
\hline Ester: Oratorio a Cinque Voci & Antonio Sacchini & 1774 \\
\hline
\end{tabular}

Quadro 3: Conteúdo das dos três tomos de Opere Varie ([17--]a, [17--]b, [17--]c), conservado na seção de Obras Raras do Grêmio Literário e Recreativo Português do Pará.

Por fim, aponta-se a existência de um exemplar do libreto de Alessandro Nell'Indie, de Pietro Metastasio (1760), impresso por ocasião de sua representação em Lisboa, no aniversário da rainha D. Maria Anna Vittoria, com música de David Perez, em 1760. Merecem destaque as gravuras dos cenários da ópera que integram o libreto (Fig. 20 e 21). 


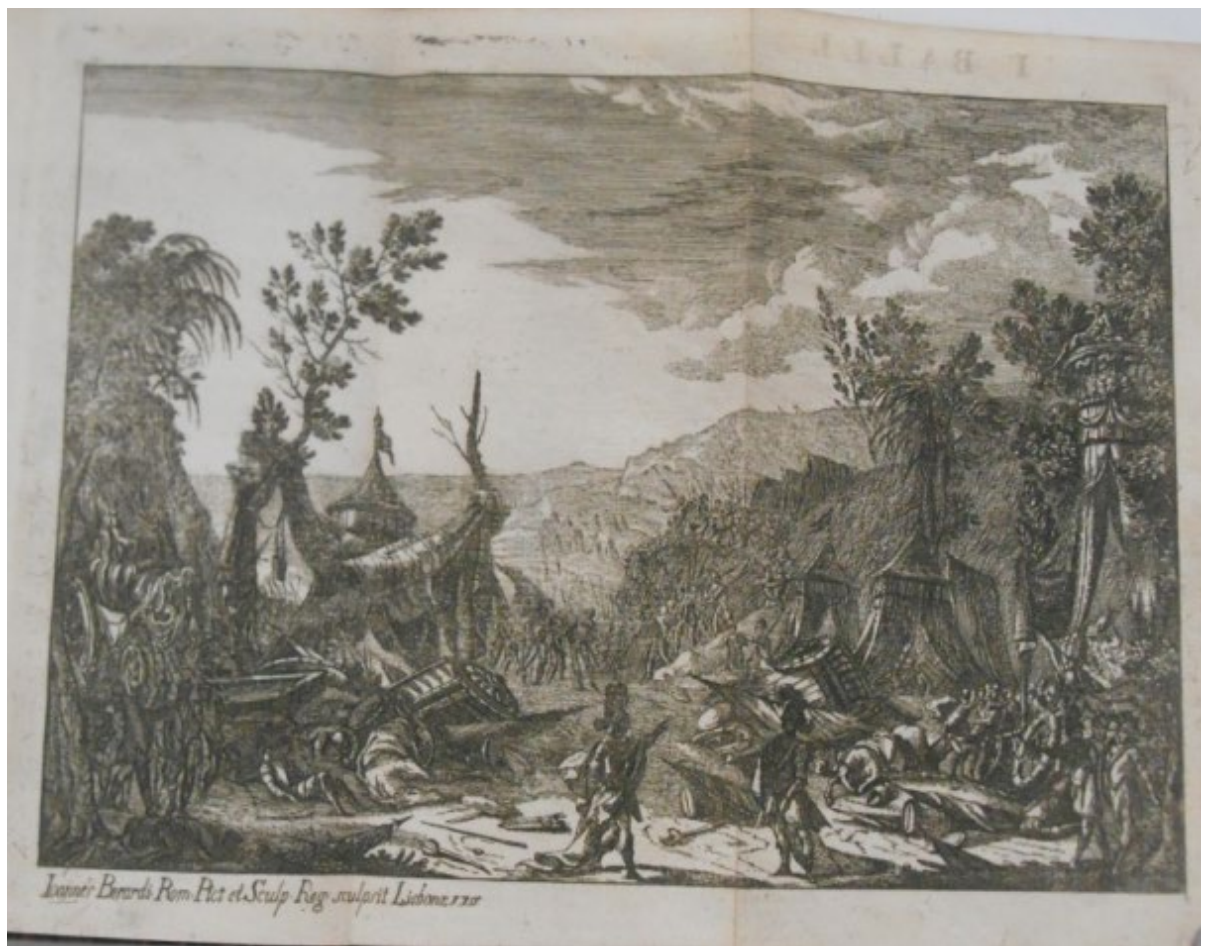

Fig. 20: Gravura no libreto de Alessandro Nell'Indie (METASTASIO, 1760, f.7), item que integra a coleção especial de obras raras da Biblioteca Fran Paxeco.

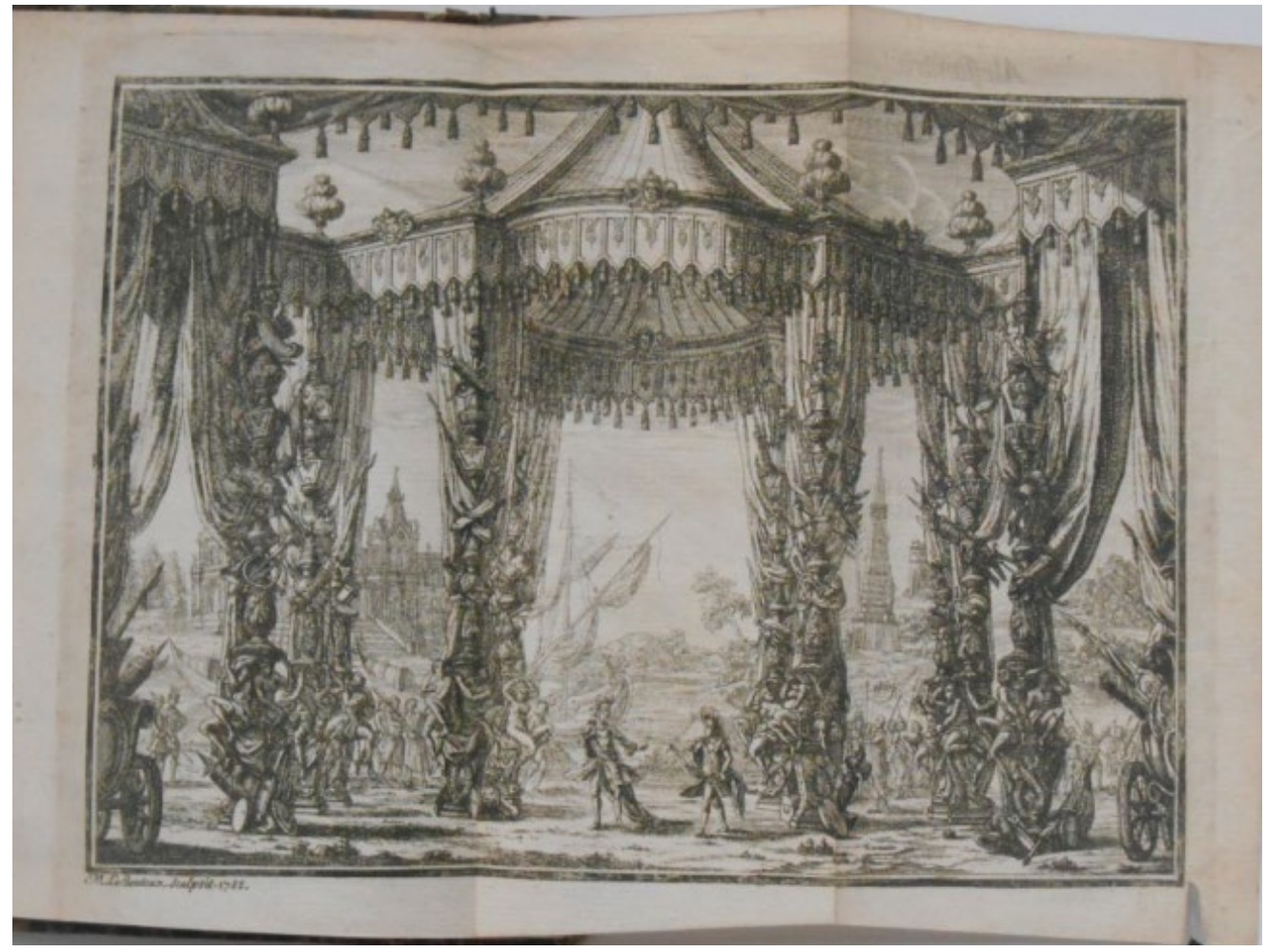

Fig. 21: Gravura no libreto de Alessandro Nell'Indie (METASTASIO, 1760, f.16), item que integra a coleção especial de obras raras da Biblioteca Fran Paxeco.

Quanto às marcas de proveniência ou sinais distintivos, o volume traz uma estampa que contém o brasão de Portugal e uma anotação manuscrita no verso da folha de 
rosto com sua tradução para o português. Não existem, entretanto, neste volume e nos demais que contêm os libretos, quaisquer indicações de que tenham chegado à Amazônia em época próxima à sua impressão.

\section{Considerações finais}

Ao final deste trabalho, é necessário trazer à memória que sequer é possível ter uma estimativa da quantidade de acervos musicais no Brasil, uma vez que estes se encontram recolhidos nas mais diversas condições: arquivos pessoais e familiares, acervos de bandas de música, de igrejas, teatros, instituições destinadas ao ensino de música, escolas, mas também bibliotecas. Como se viu no primeiro item do trabalho, as bibliotecas brasileiras podem recolher às suas coleções livros de considerável antiguidade, como é o caso dos volumes das bibliotecas Nacional e do Estado de Minas Gerais, mas também de raridade comprovada, como é o caso da biblioteca pessoal de D. Pedro Gastão de Orleans e Bragança, em Petrópolis (RJ), e da Seção de Obras Raras da biblioteca que recolhe o volume único conhecido do Manuale mercedário dos frades do Grão-Pará, mas também um livro menos raro, que, em razão das marcas de proveniência, é capaz de contar da fundação da própria biblioteca, razão pela qual integra seu acervo fundador (CATALDO; LOUREIRO, 2019).

Embora exista um Guia do patrimônio bibliográfico nacional de acervo raro (BIBLIOTECA NACIONAL, 2012), foram apontadas as limitações do procedimento na coleta de dados que embasaram sua produção. Ademais, apenas uma parte das bibliotecas do país que foram visitadas em pesquisa de campo possui catálogo disponível para consulta remota e, mesmo quando possui, há casos em que alguns itens não constam na base de dados. Assim, embora as bibliotecas também tenham o papel de custodiadoras de fontes de interesse musical, ainda há um grande trabalho a ser desenvolvido. Quando os acervos dessas bibliotecas são estudados como coleções de fato, de maneira a observar as conexões entre os diversos itens que os integram, seu estudo permite que sejam constatadas intenções de se constituírem ou legitimarem identidades, gerando pertencimento à comunidade de consulentes.

O acervo da Biblioteca Fran Paxeco do Grêmio Literário e Recreativo Português do Pará revela claramente este interesse identitário, de maneira a preservar, entre os imigrantes, um sentimento de pertencimento cultural. Se, por um lado, a biblioteca revela um caráter universal, com os principais autores em circulação na segunda metade do século XIX e início do XX, por outro, fica evidente a grande quantidade de autores portugueses e de obras impressas em Portugal. Na Seção de Obras Raras, resta clara a afirmação de uma identidade eminentemente lusitana no campo da música, porém luso-amazônida quando se observa sua coleção de maneira mais ampla. Os itens de maior interesse musical foram os textos sobre música, que foram escritos, em parte, por teólogos, os livros de teoria e cantochão, o Manuale Processionum (1733), dos agostinianos descalços de Portugal, e a extensa coletânea de libretos, parte deles representada em Lisboa, no Teatro da Rua do Conde. 
A abordagem aqui proposta, de observação dos acervos como conjuntos capazes de revelar memórias e identidades coletivas, e não apenas como simples justaposição de documentos, tem sido empregada há algum tempo para o estudo de acervos de bandas de músicas e instituições religiosas, mas também se revelou eficiente no estudo da coleção especial de uma biblioteca. O estudo das marcas de proveniência, bastante consolidado na área da Biblioteconomia, foi fundamental para a reconstituição da história de cada item.

Embora inexistam, nos itens da Seção de Obras Raras da Biblioteca Fran Paxeco, marcas de proveniência capazes de embasar qualquer inferência do uso de tais fontes em práticas musicais no atual território do Brasil ao tempo de sua produção - tais como menções a algum teatro ou às casas religiosas do Pará, a exemplo das jesuíticas de Santo Alexandre e Vigia ou do convento da Natalidade, dos mercedários -, nem por isso o acervo se torna menos interessante do ponto de vista do estudo das memórias e identidades por meio da constituição do acervo.

Do mesmo modo que a Biblioteca Fran Paxeco do Grêmio Literário e Recreativo Português do Pará, existe uma enorme quantidade de coleções bibliográficas no Brasil que ainda não foi estudada do ponto de vista da Musicologia. Considerando que os estudos musicais se concentraram nos arquivos de bandas, igrejas e outras coleções de documentos musicográficos, os acervos das bibliotecas ainda constituem uma longa via a ser trilhada.

\section{Referências}

ABUD, Oneide Silva et al. Catálogo de obras raras: séc. XVI. Belém: UFPA; Bibl. Fran Paxeco, 1985a.

ABUD, Oneide Silva et al. Catálogo de obras raras: séc. XVII. Belém: UFPA; Bibl. Fran Paxeco, 1985b.

ABUD, Oneide Silva; MOTA, Regina Ruth Pinto; SANTIAGO, Sonia Margareth (Org.). Catálogo de obras raras: séc. XVIII. Belém: UFPA; Bibl. Fran Paxeco, 1985.

ALVES, Pedro; ORTEGA, Pepita. Livros raros são descobertos em acervo de biblioteca do Pará: Biblioteca Fran Paxeco, em Belém, conta com cerca de 40 mil livros antigos, e algumas raridades foram encontradas. Estadão, São Paulo, 12 nov. 2018. Caderno Cultura. Disponível em: https://cultura.estadao.com.br/noticias/literatura,livros-rarossao-descobertos-em-acervo-de-biblioteca-do-para,70002603916. Acesso em: 14 nov. 2018.

ASSUMPÇÃO, José da. Hymnologia Sacra em Seis Partes Igualmente Dividida: Parte primeira, na qual com grande variedade de Textos da Sagrada Efcritura, authoridades dos SS. PP. e muitas noticias das hiftorias humanas, se explanaõ todos os Hymnos do 
Tempo do Breviario, e alguns mais de alguns Santos, que por devoçaõ fe acrefcentaraõ a efta primeira parte. Obra utilissima para os examinandos e naõ menos para os Prègadores... Lisboa Ocidental: [Off.] Jozè Francisco, 1738. Exemplar disponível em: https://books.google.com.br/books?id=YWOVZkT0100C. Acesso em: 8 jan. 2020.

AUGUSTI, Valéria. Considerações sobre a constituição do acervo do Grêmio Literário Português de Belém do Pará. In: CONGRESSO DE LEITURA DO BRASIL, 17., 2009, Campinas-SP. Anais [...] Campinas: UNICAMP, 2009. 5 p. Disponível em: http://alb.com. br/arquivo-morto/edicoes_anteriores/anais17/. Acesso em: 10 jun. 2018.

BELLOTTO, Heloísa Liberalli. Arquivística: objetos, princípios e rumos. São Paulo: Associação de Arquivistas de São Paulo, 2002.

BELLOTTO, Heloísa Liberalli. Arquivo: estudos e reflexões. Belo Horizonte: Ed.UFMG, 2014.

BIBLIOTECA NACIONAL. Guia do Patrimônio Bibliográfico Nacional de Acervo Raro. Rio de Janeiro: Ministério da Cultura; Fundação Biblioteca Nacional, 2012.

BUSENELLO, Francesco. [Coletânea com vários libretos]. Venetia: Andrea Giuliani, 1656. Seção de Obras Raras da Biblioteca Fran Paxeco, Localização: 1656.

CAMARGO, Ignacio. Discurso theologico, sobre los theatros, y comedias de este siglo: en que por todo genero de autoridades, en especial de los Santos Padres de la Iglesia, y Doctores Escolasticos, y por principios solidos de la Theologia, se resuelve con claridad la question, de si es, ò no, pecado grave el ver comedias, como se representan oy en los theatros de España. Lisboa: Emprenta de Miguel Manescal, 1690. Exemplar disponível em: http://purl.pt/14221. Acesso em: 8 jan. 2020.

CANDAU, Joël. Memória e identidade. São Paulo: Contexto, 2011.

CASTAGNA, Paulo. Uma análise paleoarquivística da relação de obras do arquivo musical de Florêncio José Ferreira Coutinho. In: ENCONTRO DE MUSICOLOGIA HISTÓRICA, 6., 2004, Juiz de Fora-MG. Anais [...] Juiz de Fora: Centro Cultural Pró-Música, 2006. p.38-84. Disponível em: https://archive.org/details/ UmaAnalisePaleoarquivisticaDaRelacaoDeObrasDoArquivoMusicalDe. Acesso em: 17 dez. 2019.

CATALDO, Fabiano; LOUREIRO, Maria Lucia de Niemeyer Matheus. Afinal, os Objetos Falam? Reflexões sobre Objetos, Coleções e Memória. In: ENCONTRO NACIONAL DE PESQUISA EM CIÊNCIA DA INFORMAÇÃO, 20., 2019, Florianópolis. Anais [...] Florianópolis: ENANCIB, 2019. p.1-20. Disponível em: https://conferencias.ufsc.br/ index.php/enancib/2019/paper/view/951. Acesso em: 13 mai. 2020. 
CATALOGO DA Bibliotheca do Gremio Litterario Português do Pará. Lisboa: Typographia e Stereotypia Moderna, 1893. Disponível em: http://fcp.pa.gov.br/201611-24-18-22-47/catalogo-da-bibliotheca-do-gremio-litterario-portugues-do-para. Acesso em: 17 dez. 2019.

CATALOGO DOS Livros q.e se axam na Livraria do Conv.to de N. S.ra da Graça de Lisboa. [Lisboa]: cópia de Francisco da Asumpsam, 1751. Disponível em: http://purl. pt/24993. Acesso em: 10 jun. 2018.

[COLEÇÃO de tratados em Alemão Gótico: 1578-1701]. Coletânea de tratados comerciais escritos em holandês, [17--], [vários locais de impressão]. Seção de Obras Raras da Biblioteca Fran Paxeco, Localização: 1578.

COMEDIE VARIE. v. 81. - Coletânea de libretos impressos, [17--]. Seção de Obras Raras da Biblioteca Fran Paxeco, Localização: 1688.

CONSTANTINENSI, R. P. F. Ioan. Michaële. Psalterium Decachordum: In quo traditur Methodus vtiliffima, tùm ad ftabiliendam fub Pfalmodia \& Oratione vocali attentionem $\&$ deuotionem: tùm ad ufum variorum Dei nominum, $\&$ obfecrationum, ac petitionũ falutarium: quæ hîc proponuntur \& explicantur, vt $\&$ eis femper \& vbique fomentur, $\&$ iaculatoriæ ad Deum orationes, ad proficiendum in amore Dei non parum vtiles. Lvngdvn [Lyon, França]: Ioan. Baptista Bvysson, 1598. Exemplar disponível em: https:// books.google.com.br/books? id=noehMJjg4DkC. Acesso em: 8 jan. 2020.

D'ACUGNA, Christophle. Relation de la Riviere des Amazones, Traduite, Par feu Mr. de Gomberville ... de l'Academie Françoife, Sur l'Original Efpagnol Du Pere Christophle D'Acugna Jefuite Sur la Copie imprimée à Paris en 1682. v. 3. Paris: [s.n.], [1682?]. Exemplar disponível em: https://books.google.com.br/books?id=dqq5LXxfMP4C. Acesso em: 8 jan. 2020.

DUARTE, Fernando Lacerda Simões. Princípios Arquivísticos, Características dos Documentos de Arquivo e as Particularidades dos Acervos Musicais: (des)caminhos do estudo das práticas musicais a partir de documentos musicográficos observados em arquivos e coleções da região amazônica. In: CONGRESSO DA ANPPOM, 29., 2019, Pelotas-RS. Anais... Pelotas: ANPPOM, 2019. p.1-9. Disponível em: http://anppom.com. br/congressos/index.php/29anppom/29CongrAnppom/paper/view/5574. Acesso em 15 mai. 2020.

EZQUERRO ESTEBAN, Antonio. Desafios da Musicologia Panhispanica na atualidade: uma reflexão. In: ROCHA, E.; ZILLE, J. A. B. (org.). Musicologia[s]. Belo Horizonte: EdUEMG, 2016. p. 25-40. Disponível em: http://eduemg.uemg.br/images/livros-pdf/ catalogo-2016/2016_MUSICOLOGIAS_SERIE_DIALOGOS_COM_O_SOM_VOL_3.pdf. Acesso em: 10 mar. 2020. 
FERLUS, Charles. Le Service Paroissial: contenant 50 morceaux, Communions, Elévations, Entrées, etc. Paris: Alfred Ikelmer et Cie., [1876]. Coletânea de partituras.

GABY, André Alves. Documentos para História da Prática Musical dos Mercedários do Convento da Natalidade do Grão-Pará. In: BARROS, Líliam; SEVERIANO, Rafael (org.). Arqueologia Musical Amazônica. Belém-PA: Paka-Tatu, 2018. p. 39-58.

GABY, André Alves. O segundo volume dos mercedários do convento do Pará. In: CONGRESSO INTERNACIONAL DE MÚSICA SACRA, 2., 2019, Rio de Janeiro. Anais [...] Rio de Janeiro: UFRJ, 2019. No prelo.

GIURGEVICH, Luana; LEITÃO, Henrique. Clavis Bibliothecarum: catálogos e inventários de livrarias de instituições religiosas em Portugal até 1834. Lisboa: Secretariado Nacional para os Bens Culturais da Igreja, 2016.

GÓMEZ GONZÁLEZ, Pedro José et al. El Archivo de los Sonidos: la gestión de fondos musicales. Salamanca: Asociación de Archiveros de Castilla y León, 2008.

GRADUALE ROMANUM: complectens Missas omnium Dominicarum et Festorum duplicium et semiduplicium totus anni necnon officium nocturnum Nativitatis Domini et praecipua processiones | Cantu reviso juxta manuscripta vetustissima. Parisiis: Jacobum Lecokere et Socios, 1862.

INSTITUTIO sive Fundatio Ordinis Sanctissimae, ac individuae Trinitatis \& Redemptionis Captivorum. Vlyssippone [Lisboa]: Emmanuel de Lyra Typ., 1591.

LÉVI-STRAUSS, Claude. O Pensamento Selvagem. 2. ed. São Paulo: Ed. Nacional, 1976.

LUCENSIS, S. P. Hippolyti Marraccii. Josephi Hymnographi, ... Mariale: quo ejusdem S. Josephi de augustissima coeli terraeque regina Deipara Virgine Maria opera omnia quae reperiri potuerunt, ex graecis $\mathrm{mm}$. ss. codicibus collecta, latine reddita notisque illustrata, nunc primo publicantur studio ac labore. Romae: Typis Ignatij de Lazaris, 1661.

MAGALANICUS, Philippus. Cantum Ecclesiasticum Praecibus apud Deum Animas Juvandi, Corporaque Humandi Defunctorum Officium, Missa et Stationes justa Ritum Sacrosanctae Romanae Ecclesiae Ominum Ecclesiarum Matris et Magristrae: Juxta Breviarij,Miffalifque Romani noviffimam recognitionem. Ulyssipone Occidentali: Thypographia Antonij Pedrozo Galran, 1720. Exemplar disponível em: https://digitalisdsp.uc.pt/bg6/UCBG-Ml-109/globalltems.html. Acesso em: 8 jan. 2020. 
MANUALE Processionum cum Benedictionibus Solemnibus, Privatisque Omnibus, Quibus Utitur Sancta Romana Ecclesia, \& Precibus, Aliisque Quamplurimis, Omnibus Officium Romanum Persolventibus Inserviens, Collectum Opera, et Industria Fratrum Ordinis Eremitarum ac Descalceatorum S. Augustini in Regno Portugalliae. Ulyspone Orientali: Typographia Augustiniana, 1733. Localização: SOR, Biblioteca Fran Paxeco, catálogo, v.3, n. 30 (1733). Exemplar disponível em: https://almamater.uc.pt/ptpt/fundo_antigo/manuale_processionum_cum_benedictionibus_solemnibus_ privatisque_omnibus_quibus_utitur. Acesso em: 10 set. 2018.

METASTASIO, Pietro. Alessandro Nell'Indie: Dramma Per Musica da Rappresentarsi Nel Gran Teatro Nuovamente Eretto Alla Real Corte Di Lisbona Nella Primavera Dell' anno MDCCLV Per Festeggiare II Felicissimo Giorno Natalizio di sua Maestà Fedelissimo D. Maria Anna Vittoria Regina Di Portogallo, Algarve, \&c. Per Comando Della Sacra Real Maestà Del Re Fedelissimo Nostro Signore [...] La Musica e del Sig.e David Perez [...]. Lisbona: Regia Stamperia Sylviana, 1760. Exemplar disponível em: http://objdigital. bn.br/acervo_digital/div_musica/libretos/mas1221056.pdf. Acesso em: 16 out. 2019.

MONTENEGRO, Antonio Torres et al. História: cultura e sentimento; outras histórias do Brasil. Recife: Ed. Universitária da UFPE; Cuiabá: Ed. da UFMT, 2008.

MOUREN, Raphaële. Manuel du Patrimoine en Bibliothèque. Paris: Electre - Éditions du Cercle de la Libraire, 2007.

NORA, Pierre. Entre a Memória e a História: a Problemática dos Lugares. Projeto História, São Paulo, n.10, p.7-28, dez. 1993. Disponível em: https://revistas.pucsp.br/ index.php/revph/article/view/12101/0. Acesso em: 10 jan. 2019.

OBRAS VARIAS. Coletânea de manuscritos e impressos, [Portugal, 17--]. Seção de Obras Raras da Biblioteca Fran Paxeco, Localização: 1762 - Sentença do Parlamento de Pariz.

OLISIPO: Boletim do grupo "Amigos de Lisboa", Lisboa, a. 10, n. 38, abr. 1947. Disponível em: http://hemerotecadigital.cm-lisboa.pt/Periodicos/Olisipo/1947/N38/ N38_master/Olisipo_N38_Abr1947.PDF. Acesso em: 10 jan. 2020.

OPERE VARIE. v. 1. Coletânea de libretos impressos de óperas representadas em Portugal. [17--]a, [Portugal]. Seção de Obras Raras da Biblioteca Fran Paxeco, Localização: 1772-1773.

OPERE VARIE. v. 2. Coletânea de libretos impressos de óperas representadas em Portugal. [17--]b, [Portugal]. Seção de Obras Raras da Biblioteca Fran Paxeco, Localização: 1773. 
OPERE VARIE. v. 3. Coletânea de libretos impressos de óperas representadas em Portugal. [17--]c, [Portugal]. Seção de Obras Raras da Biblioteca Fran Paxeco, Localização: 1773-1775.

PLATI, Hieronymo. Libro del bien del estado religioso: compuesto... Medina el Campo : Santiago del Canto, 1595. Seção de Obras Raras da Biblioteca Fran Paxeco, Localização: 1595.

PROCESSIONARIVM Monasticvm Ivxta Consvetvdinem Monachorum Nigrorum Ordinis S. P. N. Benedicti Regnotum Portugaliae. Conimbricae [Coimbra]: Off. Didacum Gomez de Loureyro, 1620. Disponível em: http://saobento.org/livrosraros/?p=164. Acesso em: 10 jan. 2020.

RÖHL, Alexandre Cerqueira de Oliveira. O Solfejo Heptacórdico de Luís Álvares Pinto e a Teoria Musical Luso-Brasileira do século XVIII. São Paulo, 2016. 535 f. Tese (Doutorado em Música). Instituto de Artes, Universidade Estadual Paulista "Júlio de Mesquita Filho", São Paulo, 2016. Disponível em: https://repositorio.unesp.br/ handle/11449/144346. Acesso em: 12 abr. 2020.

SACROSANCTI ET OECUMENICI CONCILII TRIDENTINI Paulo III. Iulio III \& Pio IIII Pont. Maximo celebrati, canones et decreta... Lvngdvni [Lyon, França]: Gvliel Rovllivm, 1580.

SANCTIAGO, Hernando de. Consideraciones sobre Todos los Evangelhos de los Domingos, y Fiestas de La Quaresma. Lisboa: Antonio Aluarez, 1595.

SALOMÃO, Kathia. O ensino de música no Maranhão: uma análise nos livros escolares de Perdigão (1869) e Rayol (1902). Cadernos de História da Educação, v.18, n.3, p.712730, 2019. Disponível em: http://www.seer.ufu.br/index.php/che/article/view/51742. Acesso em: 12 mai. 2020.

SOBRINO, Alonso. Tratado de La Inmaculada Concepción de la Virgen Maria N. S.: dirigido al... Sevilla: Gabriel Vejarano, 1615. Seção de Obras Raras da Biblioteca Fran Paxeco, Localização: 1615.

SYLVA, Manoel Nunes. Arte minima, que com semibreve prolaçam tratta em tempo breve, os modos da maxima, \& longa sciencia da musica, offerecida a sacratissima Virgem Maria senhora nossa, debaixo da invocação da Quietaçam, cuja imagem esta em a Santa Sé desta cidade, por seu author o P. Manoel Nunes da Sylva, mestre cathedratico do collegio de S. Catharina do illustrissimo senhor arcebispo \& do coro da parochial igreja de santa Maria Magdalena, na qual foi baptizado. Lisboa: Officina de Miguel Manescal, 1704. Exemplar disponível em: https://www.loc.gov/resource/ muspre1800.101320/?st=gallery. Acesso em: 15 mar. 2020. 
VASCONCELLOS, Joaquim de. Os Musicos Portuguezes: biographia - bibliographia. 2 v. Porto: Imprensa Portugueza, 1870. Exemplar disponível em: https://archive.org/ details/osmusicosportug01vascgoog. Acesso em: 15 mar. 2020.

VILLA-LOBOS, Mathias de Souza. Arte de Cantochão: offerecida ao illustrissimo Dom loam de Mello... Coimbra: Manoel Rodrigues de Almeyda, 1688. Exemplar disponível em: https://imslp.org/wiki/Arte_de_cantoch\%C3\%A3o_(Villa-Lobos\%2C_Mathias_de_ Sousa). Acesso em: 15 mar. 2020.

ZEFERINO, Francisco Rey de Abreu. Anatomico Jocoso: que em diversas operaçoens manifefta a ruindade do corpo humano, para emenda do viciofo... v. 1. Lisboa: Off. Do Doutor Manoel Alvarez Solano, 1760. Exemplar disponível em: http://purl.pt/6526. Acesso em: 15 mar. 2020. 